\title{
saki
}

Studi Akuntansi \& Keuangan Indonesia

\section{Akuntansi Hak Konsesi sebagai Aset Tak Berwujud pada Perusahaan Penyedia Jasa Jalan Tol di Indonesia}

\author{
Sony Indra Baskoro, Amrie Firmansyah \\ Politeknik Keuangan Negara STAN \\ Sektor V Bintaro Jaya, Jl. Bintaro Utama 3A, \\ Jurang Manggu Timur, Kec. Pondok Aren, Kota Tangerang Selatan, Banten 15222
}

\section{Kata Kunci: \\ Konsesi, Jalan Tol, Standar Akuntansi \\ Keuangan, Pengungkapan, Implementasi}

Keywords:

Concession, Toll Road, Financial Accounting Standards, Disclosure, Implementation

Corresponding author: amrie.firmansyah@gmail. com

\begin{abstract}
Abstrak
Penelitian ini bertujuan untuk mengulas implementasi dan pengungkapan hak konsesi jalan pada laporan keuangan perusahaan penyedia jasa jalan tol. Penelitian ini menggunakan metode kualitatif dengan teknik analisis isi dan wawancara. Data yang digunakan dalam analisis isi ini yaitu laporan keuangan PT Citra Marga Nusaphala Persada Tbk dan PT Jasa Marga (Persero) Tbk selaku perusahaan penyedia jasa jalan tol di Indonesia mulai tahun 2014 sampai dengan tahun 2018. Sementara itu, wawancara dilakukan kepada dua informan yang memiliki keahlian terkait dengan implementasi atas akuntansi untuk konsesi jalan tol. Penelitian ini menyimpulkan bahwa implementasi akuntansi atas hak konsesi jalan tol sudah sesuai dengan standar akuntansi keuangan yang berlaku dan pengungkapan akuntansi atas hak konsesi sudah sesuai dengan standar akuntansi keuangan yang berlaku. Informasi yang diungkapkan oleh perusahaan yang menyelenggarakan hak konsesi jalan tol bermanfaat bagi pemangku kepentingan dalam pengambilan keputusan.
\end{abstract}

\section{Abstract}

This study aims to review the implementation and disclosure of road concession rights in toll road service providers' financial statements. This research uses qualitative methods with content analysis and interview techniques. The data used in the content analysis are the financial statements of PT Citra Marga Nusaphala Persada Tbk and PT Jasa Marga (Persero) Tbk as a toll road service provider in Indonesia from 2014 to 2018. Meanwhile, interviews were conducted with two informants who have expertise related to accounting for toll road concessions. This study concludes that the implementation of accounting for toll road concession rights is following the applicable financial accounting standards and accounting disclosures for concession rights are under applicable financial accounting standards. The information disclosed by the company that operates toll road concession rights is useful for stakeholders in making decisions. 


\section{saki}

Studi Akuntansi \& Keuangan Indonesia

\section{Pendahuluan}

Pentingnya keberadaan dan ketersediaan infrastruktur membuat pemerintah senantiasa mengusahakan keberadaan fasilitas umum yang dapat menunjang kegiatan masyarakat. Pembangunan infrastruktur yang dilakukan secara masif oleh pemerintah belakangan ini diharapkan dapat menjadi penggerak dan pendukung perekonomian masyarakat (Setkab, 2017). Dalam Narasi Rencana Pembangunan Jangka Menengah Nasional 2019-2024 (Bappenas, 2019) disebutkan total kebutuhan dana untuk membangun infrastruktur sebesar Rp6.421 triliun. Dari total kebutuhan dana tersebut, pemerintah hanya mampu memenuhi sebesar 3,46 persen dari PDB. Untuk menutup selisih kebutuhan dana tersebut, pemerintah mengajak masyarakat dan badan usaha untuk berpartisipasi dalam kegiatan penyediaan infrastruktur tertentu yang dibutuhkan oleh masyarakat. Salah satu cara yang dilakukan oleh pemerintah yaitu dengan menjalankan skema Kerjasama Pemerintah dengan Badan Usaha (KPBU).

Untuk mendukung skema tersebut, Presiden menerbitkan Peraturan Presiden Nomor 38 Tahun 2015 tentang Kerjasama Pemerintah dengan Badan Usaha dalam Penyediaan Infrastruktur. Dalam peraturan tersebut dijelaskan bahwa KPBU merupakan kerja sama yang dilakukan oleh pemerintah dengan menggandeng badan usaha untuk membangun infrastruktur publik berdasarkan kriteria yang sudah ditentukan oleh pimpinan kementerian/ lembaga/ Badan Usaha Milik Negara/ Daerah dan kepala daerah. Kegiatan pembangunan fasilitas tersebut dilakukan dengan menggunakan sumber daya yang dimiliki oleh badan usaha selaku mitra pemerintah tetapi tetap memperhatikan pembagian risiko kepada pihak-pihak yang terlibat dalam perjanjian tersebut. Penggunaan sumber daya tersebut tentunya harus dapat dipertanggungjawabkan dengan transparan dan akuntabel dalam wujud laporan keuangan tahunan yang disampaikan kepada para pemangku kepentingan. Dengan terbitnya peraturan tersebut, pemerintah berharap dapat memberi kepastian hukum dan jaminan yang layak kepada badan usaha dalam menjalankan skema perjanjian ini.

Skema ini membuat banyak badan usaha baik swasta maupun milik negara berlomba-lomba untuk mengajukan penawaran pengadaan infrastruktur yang menarik kepada pemerintah atau mengusulkan proyek baru yang mengandung potensi ekonomi dan layak secara finansial. Contoh proyek besar yang 


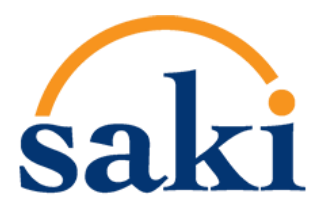

Studi Akuntansi dan Keuangan Indonesia, Vol. 3, No. 2, 2020 | E-ISSN: 2654-6221

Studi Akuntansi \& Keuangan Indonesia

sudah dan masih akan terus dibangun oleh pemerintah salah satunya adalah jalan tol. Jalan tol digunakan sebagai sarana mobilisasi masyarakat dan distribusi barang maupun jasa. Keberadaan jalan tol dapat mempersingkat waktu yang dibutuhkan untuk melakukan mobilisasi dari satu lokasi ke lokasi yang lain dan meminimalkan biaya secara secara signifikan. Pembangunan jalan dapat meningkatkan efektivitas dan efisiensi biaya yang harus dikeluarkan serta dapat meningkatkan taraf hidup masyarakat (Iek, 2013). Pembangunan infrastruktur berupa jalan dapat menarik minat investor untuk melakukan investasi penanaman modal (Sumadiasa et al., 2016).

Menurut Peraturan Pemerintah Nomor 15 Tahun 2005, badan usaha atau pihak yang mendapat persetujuan atas proyek yang diusulkan akan mendapatkan hak konsesi berupa izin untuk membangun dan mengoperasikan jalan tol yang sudah dibangun. Pemberian konsesi ini dimaksudkan agar badan usaha dapat mengembalikan dana investasi yang sudah dikeluarkan untuk menyediakan infrastruktur dan keuntungan yang diharapkan dari kerja sama penyediaan infrastruktur tersebut. Pemberian konsesi tersebut menurut pasal 33 ayat (4) Peraturan Pemerintah Nomor 27 Tahun 2014 memiliki durasi paling lama 50 tahun, atau sesuai dengan kontrak yang disepakati. Ketika masa konsesi berakhir, infrastruktur yang menjadi objek suatu kontrak akan dikembalikan kepada pemerintah untuk kemudian dikelola melalui Badan Pengatur Jalan Tol (BPJT).

Dari sudut pandang dan perlakuan akuntansi, badan usaha akan mengakui kepemilikan hak konsesi jalan tol sebagai aset tak berwujud dalam laporan keuangannya. Pengakuan tersebut dimulai ketika badan usaha menandatangani kontrak perjanjian dengan pemerintah sampai dengan berakhirnya masa perjanjian tersebut. Selain itu, seluruh kebijakan akuntansi yang dipakai akan dijelaskan secara detail dalam Catatan Atas Laporan Keuangan (CALK). Pengakuan tersebut sesuai dengan syarat yang disebutkan dalam PSAK 19 (IAI, 2015) dimana suatu aset bisa diklasifikasikan sebagai tak berwujud apabila memenuhi beberapa kriteria. Kriteria yang dimaksud yaitu apabila aset tak berwujud tersebut merupakan sumber daya milik perusahaan, dapat diidentifikasi, dapat ditentukan nilainya, dan mampu memberikan manfaat ekonomis pada masa mendatang tapi tidak memiliki substansi fisik yang nyata.

Pengakuan awal aset tak berwujud didasarkan pada harga perolehan, yaitu harga pembelian aset tersebut ditambah dengan seluruh biaya yang dikeluarkan hingga aset tersebut siap untuk digunakan atau 


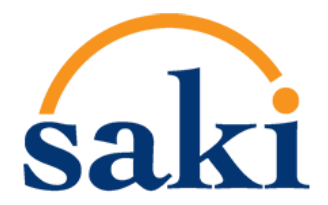

Studi Akuntansi dan Keuangan Indonesia, Vol. 3, No. 2, 2020 | E-ISSN: 2654-6221

Studi Akuntansi \& Keuangan Indonesia

dinilai pada nilai wajar saat tanggal akuisisi apabila diperoleh dari kegiatan kombinasi bisnis. Untuk amortisasi aset tak berwujud tersebut dilakukan selama masa manfaat atau nilai ekonomis, tergantung usia mana yang lebih pendek. Aset tak berwujud suatu perusahaan cukup beraneka ragam, tergantung sektor yang menjadi fokus perusahaan dalam menjalankan bisnisnya. Contoh aset tak berwujud yang dimiliki perusahaan diantaranya berupa goodwill, franchise, database, paten, lisensi, merek dagang, hubungan pelanggan, dan sebagainya (Warren et al., 2018). Dalam sektor bisnis usaha penyediaan layanan jalan tol, aset paling besar yang ada dalam laporan keuangan perusahaan berupa hak konsesi/ perjanjian kontrak jasa pengoperasian jalan tol dan diakui sebagai intangible asset yang jarang dimiliki oleh perusahaan pada umumnya. Walaupun telah diatur dalam ISAK 16 (IAI, 2014), penilaian aset konsesi belum dipahami secara luas oleh publik sebagai salah satu intangible asset, sehingga ulasan atas topik ini menjadi penting dibahas dalam suatu penelitian.

Beberapa penelitian sebelumnya telah mengulas terkait aset konsesi sebagai aset tak berwujud. Muliaditia (2014) mengulas perhitungan amortisasi intangible assets berupa hak untuk mendistribusikan air bersih dalam perjanjian konsesi jasa di PT Adhya Tirta Batam (ATB). Penelitian tersebut menyimpulkan bahwa laba rugi yang diperoleh perusahaan akan berbeda apabila amortisasi atas aset tak berwujud yang dimiliki dengan menggunakan usia pembanding berupa masa kontrak, masa komersial, dan masa fiskal. Prasetyo \& Agustia (2018) menganalisis dampak akuntansi dari adanya wacana penerapan ISAK 16 pada penyelenggaraan Prasarana Kereta Api Ringan/ Light Rail Train pada lini usaha PT Kereta Api Indonesia. Penelitian tersebut menyimpulkan bahwa munculnya masalah akuntansi pengakuan pendapatan, penurunan nilai aset tidak berwujud, dan permasalahan pengakuan aset tetap ketika perusahaan melakukan penyajian ulang laporan keuangan yang sudah diterbitkan satu tahun sebelum penerapan ISAK 16. Amini (2017) mengulas perjanjian konsesi jasa pada PT Jasa Marga (Persero) Tbk dengan objek penelitian berupa laporan keuangan tahun 2016. Penelitian tersebut menyimpulkan bahwa penerapan perjanjian konsesi jasa yang dilakukan oleh PT Jasa Marga (Persero) Tbk. sudah sesuai dengan ISAK 16 dan ISAK 22. Penelitian tersebut dapat dijadikan sebagai acuan untuk melakukan penelitian lanjutan dengan melakukan perbandingan implementasi dengan perusahaan penyedia jasa jalan tol lainnya di Indonesia. 


\section{saki}

Studi Akuntansi \& Keuangan Indonesia

Sementara itu, penelitian-penelitian lainnya hanya menguji atau mengulas aset tak berwujud bukan terkait dengan aset konsesi. Rosdini (2016) membahas dampak dari penerapan PSAK 19 terhadap aset tidak berwujud yang menjadi salah satu pendukung nilai ekuitas yang dimiliki oleh perusahaan yang terdaftar di Bursa Efek Indonesia. Abadiah et al. (2017) dan Isnaini (2016) menguji intangible asset yang dimiliki perusahaan terhadap nilai perusahaan. Firmansyah et al. (2020a) mengulas pengungkapan aset tak berwujud pada perusahaan subsektor telekomunikasi di Indonesia, sedangkan Firmansyah et al. (2020b) mengulas penyajian aset tak berwujud pada PT Telkom Indonesia. Hartanto \& Firmansyah (2019) membahas kapitalisasi aset tak berwujud pada perusahaan secara internal. Selanjutnya, penelitian lainnya mengulas aset konsesi bukan dari sudut pandang akuntansi, seperti yang dilakukan oleh Bel \& Foote (2012). Penelitian tersebut mengulas perbedaan praktik konsesi di Amerika Serikat dan Perancis dan menyimpulkan bahwa praktik konsesi di dua negara tersebut berbeda baik dari sisi struktur maupun prosedur untuk mendapatkan hak konsesi atas pengelolaan jalan tol. Berdasarkan penelitian-penelitian sebelumnya, bagaimana perlakuan akuntansi atas aset tak berwujud terkait dengan hak konsesi untuk pengelolaan jalan tol di Indonesia?

Penelitian ini bertujuan untuk mengulas implementasi akuntansi perjanjian konsesi jasa dua perusahaan yang bergerak dalam bidang penyediaan jasa jalan tol di Indonesia dalam rentang waktu lima tahun, mulai tahun 2014 sampai dengan tahun 2018. Berbeda dengan penelitian Amini (2017) yang mengulas aset konsesi sebagai aset tak berwujud berdasarkan data dan informasi laporan keuangan dalam periode satu tahun, penelitian ini berusaha untuk melengkapi penelitian tersebut dengan mengulas aset konsesi sebagai aset tak berwujud lebih mendalam. Pengakuan, pengukuran, dan pengungkapan seluruh hak dan kewajiban yang timbul dari perjanjian konsesi jasa jalan tol menjadi pokok bahasan yang diulas dalam penelitian ini. Ketepatan pengklasifikasian akun, penggunaan estimasi, dan kebijakan akuntansi yang mendekati realita di lapangan diharapkan dapat menjadikan laporan keuangan sebagai representasi kegiatan bisnis usaha perusahaan. Oleh karena itu, penelitian ini penting dilakukan karena masih jarang literatur yang mengulas implementasi akuntansi konsesi jasa yang secara spesifik membahas jasa penyediaan jalan tol dalam periode waktu tertentu di Indonesia. Penelitian ini diharapkan memberikan kontribusi terkait dengan perluasan literatur atas aset tak berwujud pada perusahan-perusahaan yang 


\section{saki}

Studi Akuntansi \& Keuangan Indonesia

melakukan layanan infrastruktur untuk masyarakat. Selain itu, penelitian ini dapat digunakan pemerintah dalam meningkatkan kebijakan terkait dengan praktik aset tak berwujud atas pelaksanaan perjanjian konsesi atau praktik kerjasama pemerintah dan badan usaha.

\section{Telaah Literatur}

Menurut Warren et al. (2018) aset jangka panjang yang digunakan dalam kegiatan operasional perusahaan, tetapi tidak memiliki substansi fisik disebut intangible asset. Tiga karakteristik yang dimiliki aset tak berwujud menurut Kieso et al., (2018), yaitu: (1) dapat diidentifikasi, (2) tidak mempunyai substansi fisik, dan (3) bukan merupakan aset keuangan. Masa manfaat yang didapatkan oleh perusahaan dari aset tak berwujud ini secara umum lebih dari satu periode akuntansi sehingga perusahaan dapat mengelompokan aset ini ke dalam jenis aset tidak lancar (non-current assets). Banyak perusahaan meletakkan aset tak berwujud setelah aset tetap dalam laporan keuangannya (Murthashidiana \& Pardede, 2015). Menurut Martani (2014), salah satu upaya yang dapat dilakukan perusahaan untuk menambah kepemilikan aset tak berwujud dapat dengan melakukan merger dan akuisisi kepemilikan entitas bisnis lain. Menurut PSAK 19 (IAI, 2015) dijelaskan bahwa aset tak berwujud merupakan aset nonmoneter teridentifikasi yang dimiliki oleh entitas tetapi tidak memiliki wujud fisik. Suatu aset disebut sebagai aset nonmoneter apabila aset tersebut tidak masuk kedalam jenis akun kas atau setara kas yang dimiliki oleh perusahaan atau merupakan aset yang akan diterima perusahaan dalam bentuk kas yang memiliki kepastian nominal dan jumlahnya dapat ditentukan.

Menurut pasal 1 UU No 38 Tahun 2004, konsesi dijelaskan sebagai hasil dari keputusan pejabat pemerintahan atau badan yang memberikan persetujuan kepada pihak lain di luar pemerintahan untuk melakukan pengelolaan fasilitas publik, dan atau fasilitas sumber daya alam atau pengelolaan lain yang sesuai dengan undang-undang yang berlaku. Menurut ISAK 16 (2014), pada paragraf 02 dijelaskan bahwa hak konsesi merupakan bentuk perjanjian yang dilakukan antara pemerintah dengan swasta dalam rangka penyediaan infrastruktur dan layanan umum kepada publik. Dalam perjanjian ini, pemerintah memiliki peran sebagai regulator dan swasta berperan sebagai operator atas infrastruktur yang akan dioperasikan. Pemerintah sebagai regulator berperan sebagai pihak yang menetapkan kontrak bersama dengan pihak swasta. Di dalam kontrak itu terdapat standar kinerja, mekanisme penyesuaian harga beserta aturan lain 


\section{saki}

Studi Akuntansi \& Keuangan Indonesia

untuk yang dapat dijadikan sebagai acuan dalam pelaksanaan kontrak yang ada. Dari segi operator, pihak swasta berperan dalam kegiatan pengembangan, pembiayaan, pengoperasian, pemeliharaan, dan peningkatan kapasitas infrastruktur dalam rangka penyediaan jasa kepada publik. Infrastruktur yang sudah siap digunakan maupun belum dibangun akan menjadi tanggung jawab operator selama masa konsesi berlangsung. Bentuk kerja sama yang dilakukan oleh pemerintah antara lain dalam bentuk skema "publik ke swasta", "bangun, operasi, serah", atau "rehabilitasi, operasi, serah".

Mengacu pada paragraf 11 ISAK 16 (2014), infrastruktur yang dioperasikan oleh swasta tidak boleh diakui dan diklasifikasikan sebagai aset tetap dalam laporan keuangannya. Hal ini dilakukan karena operator tidak memiliki hak untuk mengendalikan infrastruktur yang ada, tetapi hanya memiliki hak untuk memberikan jasa layanan kepada publik atas nama pemberi konsesi. Operator menyediakan jasa kepada publik sesuai dengan persyaratan yang sudah ditetapkan dalam kontrak guna memenuhi kepentingan pemberi konsesi.

Ada beberapa ciri yang menunjukkan bahwa sebuah perjanjian bisa diklasifikasikan sebagai perjanjian konsesi jasa. Ciri yang pertama yaitu adanya pihak operator atau swasta selaku pengelola infrastruktur yang bertugas untuk menyediakan jasa pelayanan kepada masyarakat dengan mengatasnamakan entitas sektor publik atau pemerintah. Ciri yang kedua yaitu pemberi konsesi perjanjian jasa merupakan entitas sektor publik/pemerintah, termasuk badan milik pemerintah dan entitas sektor swasta yang sudah mendapatkan hak konsesi lebih dulu. Ciri yang ketiga yaitu pihak swasta selaku operator/ penerima konsesi memiliki tanggung jawab untuk mengelola sebagian atau infrastruktur dan memberikan pelayanan jasa kepada publik. Selain itu, operator hanya bertindak sebagai agen sesuai kepentingan pemberi konsesi/pemerintah. Ciri keempat yaitu operator dapat membebankan harga yang sudah ditetapkan di awal pemberian jasa dan dapat mengusulkan perubahan harga kepada regulator selama perjanjian konsesi berlangsung sesuai dengan kesepakatan yang berlaku. Ciri kelima yaitu operator wajib untuk mengembalikan hak pengelolaan infrastruktur kepada pemberi konsesi sesuai dengan kondisi yang sudah disepakati. Operator juga dapat memberikan tambahan imbalan kepada pemberi konsesi sebesar nominal yang sudah atau akan ditentukan, tanpa melihat siapa pihak yang awalnya membiayai infrastruktur tersebut pada akhir periode perjanjian. Selain ciri umum yang disebutkan pada paragraf 03 tersebut, ISAK 


\section{saki}

Studi Akuntansi dan Keuangan Indonesia, Vol. 3, No. 2, 2020 | E-ISSN: 2654-6221

Studi Akuntansi \& Keuangan Indonesia

16 (2014) juga menyediakan kerangka akuntansi yang dapat digunakan sebagai acuan untuk menguji dan menentukan apakah perjanjian konsesi jasa yang dilakukan oleh operator dengan pemberi konsesi termasuk dalam ruang lingkup pembahasan ISAK 16.

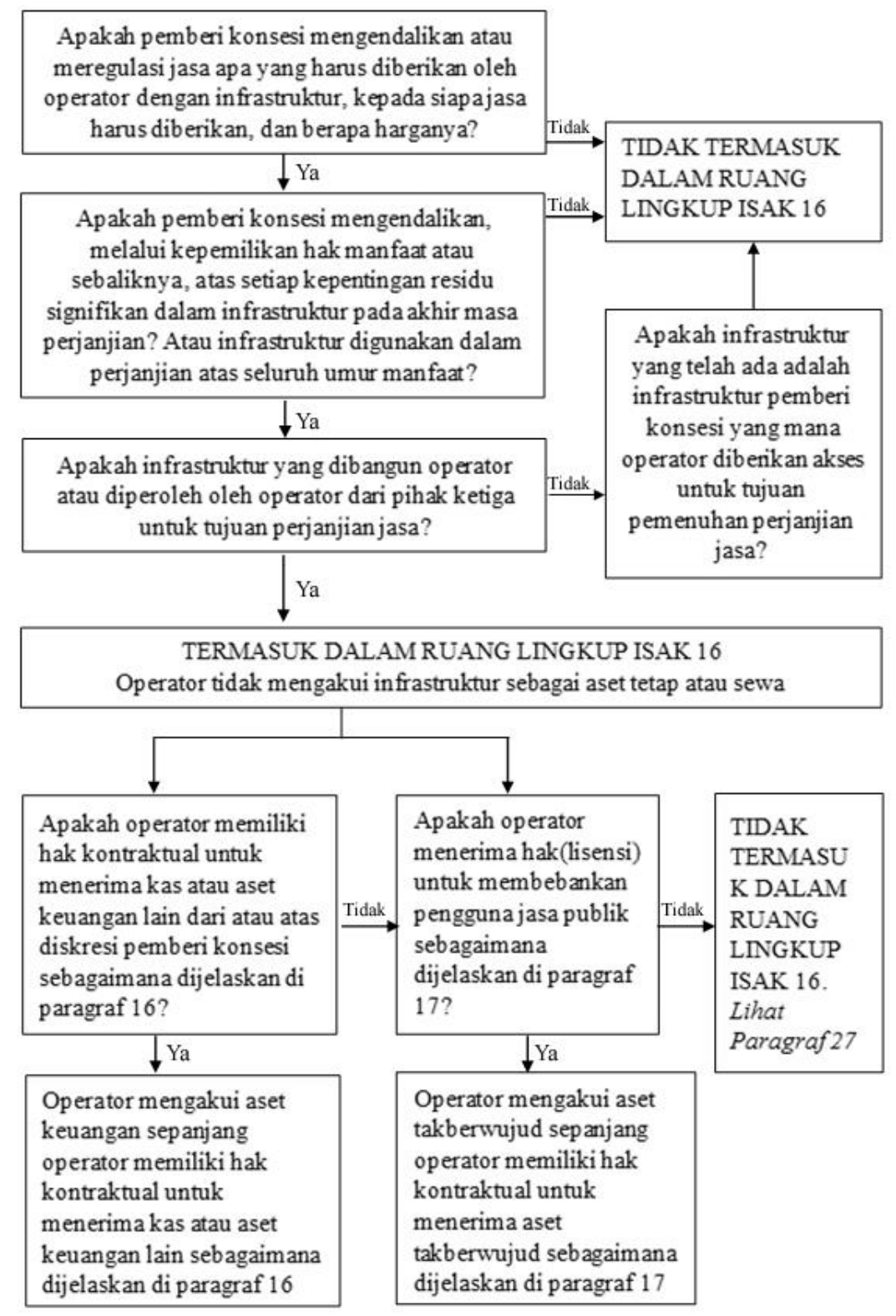

Bagan 1 Kerangka Pengujian Perjanjian Konsesi Jasa

Bagan 1 merupakan kerangka pengujian perjanjian konsesi jasa. Poin pertama yaitu menguji apakah pemberi konsesi jasa memberikan regulasi kepada operator mengenai jenis jasa yang harus 


\section{saki}

Studi Akuntansi \& Keuangan Indonesia

disediakan berkaitan dengan infrastruktur yang dibangun, siapa pengguna layanan jasa tersebut, dan tarif yang dikenakan oleh operator sebagai imbalan atas jasa yang diberikan oleh operator kepada pengguna jasa. Poin kedua yaitu menguji apakah di akhir periode perjanjian, pemberi konsesi akan menguasai infrastruktur yang digunakan untuk memberikan layanan kepada masyarakat atau tidak. Poin ketiga yaitu menguji apakah infrastruktur yang dibangun sendiri maupun diperoleh dari pihak ketiga ditujukan untuk menyediakan jasa layanan kepada penggunanya dalam rangka pelaksanaan perjanjian konsesi jasa atau tidak. Setelah ketiga pengujian tersebut selesai dilakukan dan dapat disimpulkan bahwa perjanjian tersebut masuk ke dalam ruang lingkup ISAK 16, selanjutnya dapat dilakukan pengujian lanjutan untuk menentukan bagaimana operator mengakui perjanjian tersebut dalam laporan keuangannya.

Ketika operator memiliki hak untuk menerima imbalan berupa kas atau aset keuangan lainnya dari pemberi konsesi, maka operator dapat mengacu pada paragraf 16 ISAK 16 (2014). Sebaliknya, ketika entitas tidak menerima kas atau aset keuangan lain melainkan menerima hak untuk membebankan biaya kepada pengguna atas pemakaian infrastruktur yang dibangun tersebut, maka entitas dapat mengakui perjanjian konsesi jasa sebagai aset tak berwujud dalam laporan keuangannya dan dapat mengacu pada paragraf 17 ISAK 16 (2014). Apabila pengujian menunjukkan hasil bahwa entitas tidak mendapatkan kas atau aset keuangan dan hak untuk membebankan biaya kepada penggunanya atas penggunaan infrastruktur tersebut, maka jenis perjanjian tersebut tidak masuk dalam ruang lingkup pembahasan ISAK 16, dan operator dapat memperlakukan perjanjian konsesi tersebut mengacu pada paragraf 27 ISAK 16 (2014).

Ketika operator mendapatkan imbalan berupa aset keuangan, pada paragraf 23 ISAK 16 (2014) disebutkan bahwa operator memiliki kewajiban untuk menampilkan aset keuangan dengan mengacu pada PSAK 50 (2014): Instrumen Keuangan - Penyajian. Sedangkan untuk pengakuan dan pengukurannya, perusahaan dapat mengacu pada PSAK 55 (2015): Instrumen Keuangan - Pengakuan dan Pengukuran. Untuk pengungkapan dalam laporan keuangan, perusahaan wajib mengungkapkan aset tersebut sesuai dengan PSAK 60 (2016) : Instrumen Keuangan - Pengungkapan. Lebih lanjut pada paragraf 24 dijelaskan perihal pengungkapan dalam laporan keuangan, operator dapat mengklasifikasikan imbalan tersebut menjadi tiga jenis imbalan. Ketiga jenis imbalan tersebut yaitu: (1) pinjaman yang diberikan dan piutang, (2) aset keuangan tersedia untuk dijual, dan (3) aset keuangan diukur pada nilai wajar melalui laba rugi. 


\section{saki}

Studi Akuntansi \& Keuangan Indonesia

Selanjutnya pada paragraf 25 ISAK 16 (2014), disebutkan apabila operator mengklasifikasikan aset sebagai pinjaman yang diberikan dan piutang dan aset keuangan tersedia untuk dijual, maka operator dapat menghitung beban bunga yang timbul dengan menggunakan metode perhitungan suku bunga efektif dan diakui dalam laporan laba rugi perusahaan. Pada paragraf 26 ISAK 16 (2014) disebutkan apabila operator mengklasifikasikan imbalan sebagai aset tak berwujud sesuai dengan kriteria yang disebutkan pada paragraf 17 dan 18 ISAK 16 (2014), operator dapat mengacu pada paragraf 45-47 PSAK 19 (2015) sebagai petunjuk dalam melakukan pengukuran aset tak berwujud yang didapatkan dari kegiatan pertukaran dengan aset atau aset nonmoneter atau kombinasi keduanya.

Pada paragraf 12 dan 13 ISAK 16 (2014) disebutkan bahwa operator dapat melakukan kegiatan pembangunan atau peningkatan kapasitas yang dimiliki oleh infrastruktur, mengoperasikan, dan melakukan pemeliharaan aset infrastruktur selama kontrak konsesi dalam rangka menyediakan jasa layanan kepada publik dan pendapatannya diakui dengan mengacu pada PSAK 34 (2014): Kontrak Konstruksi dan PSAK 23 (2014): Pendapatan atas kegiatan dan jasa yang sudah dikerjakan. Apabila operator menjalankan kegiatan pembangunan atau peningkatan kapasitas infrastruktur dan jasa operasi, maka operator dapat mengalokasikan imbalan yang diterima dari pekerjaan tersebut dengan mengacu pada nilai wajar imbalan atas jasa yang diberikan secara proporsional. Pengalokasian tersebut hanya dapat dilakukan apabila nilai wajar imbalan tersebut dapat diidentifikasi secara terpisah.

Pada paragraf 14 ISAK 16 (2014) disebutkan bahwa seluruh pendapatan yang diperoleh dan beban yang timbul sehubungan dengan kegiatan penyediaan jasa konstruksi atau usaha peningkatan infrastruktur dapat dicatat dengan mengacu pada PSAK 34 (2014): Kontrak Konstruksi. Sementara itu, pada paragraf 20 ISAK 16 (2014) disebutkan bahwa operator berhak mengakui pendapatan atas jasa operasi yang diberikan kepada pengguna dengan mengacu pada PSAK 23 (2014): Pendapatan. Pada paragraf 15-18 ISAK 16 (2014) disebutkan bahwa imbalan yang diterima oleh operator dinilai berdasarkan nilai wajar yang dapat diterima atau akan diterima dalam bentuk aset keuangan atau aset tak berwujud.

Pada paragraf 16 disebutkan bahwa operator dapat mengakui pendapatan yang timbul sebagai aset keuangan ketika operator mempunyai hak tanpa syarat untuk menerima kas atau aset keuangan lain dari pemberi konsesi sebagai imbalan dari kegiatan pembangunan yang dilaksamakan. Hak tanpa syarat 


\section{saki}

Studi Akuntansi \& Keuangan Indonesia

tersebut dapat diakui ketika pemberi konsesi memberikan jaminan kepada operator untuk membayar di kemudian hari sejumlah nominal tertentu atau yang dapat ditentukan. Selain itu, hak tanpa syarat tersebut juga bisa diakui ketika timbul selisih dari kegiatan transaksi pembayaran yang dibayarkan oleh pengguna jasa publik dengan jumlah tertentu/ dapat ditentukan. Kemudian pada paragraf 17 disebutkan bahwa operator dapat mengakui sebagai aset tak berwujud ketika operator mendapatkan hak / lisensi untuk melakukan pembebanan biaya kepada pengguna jasa publik. Hak pembebanan yang dimiliki oleh operator tersebut bukan termasuk hak kontraktual tanpa syarat untuk menerima kas, karena jumlahnya bergantung kepada pemakaian jasa publik yang disediakan oleh operator. Lebih lanjut pada paragraf 18 disebutkan ketika operator dibayar menggunakan kombinasi aset keuangan dan aset tak berwujud, imbalan yang diterima oleh operator tersebut dinilai dengan menggunakan nilai wajar dan dicatat terpisah sesuai dengan alokasi nilai wajarnya. Imbalan yang akan diterima oleh operator dapat ditentukan menurut syarat kontrak atau hukum kontrak yang sesuai dengan perjanjian tersebut.

Pada paragraf 21 ISAK 16 (2014) disebutkan bahwa operator mempunyai kewajiban tertentu yang melekat dan tertuang dalam kontrak perjanjian konsesi dengan pemerintah. Kewajiban tersebut berupa kewajiban untuk memelihara infrastruktur pada tingkat kemampuan tertentu dan kewajiban untuk memulihkan infrastruktur sesuai dengan kondisi yang sudah ditentukan sebelum aset tersebut diserahkan kepada pemberi hak konsesi di akhir periode perjanjian. Berkaitan dalam hal itu operator mengakui dan mengukur kewajiban tersebut dengan mengacu pada PSAK 57 (2015): Provisi, Liabilitas Kontijensi, dan Aset Kontijensi. Dalam praktiknya, manajemen dapat menggunakan estimasi terbaik yang dimiliki untuk menghitung biaya yang akan dikeluarkan dalam rangka meyelesaikan kewajiban masa kini atas infrastruktur tersebut di akhir periode.

Pada paragraf 22 ISAK 16 (2014) disebutkan apabila operator membangunan aset infrastruktur dengan meminjam dari pihak lain dan menanggung biaya pinjaman tersebut, seluruh biaya yang timbul dapat dibebankan sesuai dengan periode peminjaman yang berlaku. Akan tetapi, pembebanan ini dikecualikan untuk operator yang menerima aset tak berwujud sebagai imbalan dalam perjanjian konsesi jasa tersebut. Ketika operator memiliki hak tersebut, biaya pinjaman yang timbul dapat dikapitalisasikan ke 


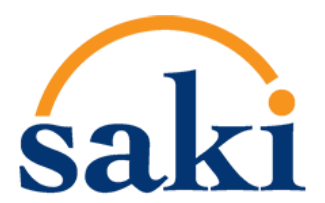

Studi Akuntansi dan Keuangan Indonesia, Vol. 3, No. 2, 2020 | E-ISSN: 2654-6221

Studi Akuntansi \& Keuangan Indonesia

dalam aset konsesi selama proses pembangunan dan dapat mengacu pada PSAK 26 (2018): Biaya Pinjaman.

Selanjutnya mengenai hak yang diberikan oleh pemberi konsesi kepada operator, hal ini dijelaskan pada paragraf 27 ISAK 16 (2014). Sesuai dengan paragraf 11 ISAK 16 (2014), infrastruktur yang dikelola oleh operator dalam rangka perjanjian jasa tidak boleh diakui sebagai aset tetap oleh operator. Selain itu, pemberi konsesi juga dapat memberikan item lain kepada operator untuk selanjutnya disimpan atau dipakai sesuai dengan kepentingan operator. Apabila suatu aset diberikan oleh pemberi konsesi kepada operator sebagai bagian dari imbalan yang diberikan pemberi konsesi atas jasa yang dilakukan, maka aset tersebut tidak dianggap sebagai hibah dari pemerintah. Pada saat pengakuan awal, aset tersebut diukur pada nilai wajar dan diakui sebagai aset operator. Dari sisi operator, operator mengakui adanya utang yang timbul karena adanya kewajiban yang belum terlaksana sehubungan dengan pertukaran aset tersebut.

Pengungkapan perjanjian konsesi jasa dalam diatur dalam ISAK 22 (2014): Perjanjian Konsesi Jasa - Pengungkapan. Pada paragraf 06 disebutkan bahwa entitas harus mengungkapkan dalam laporan keuangannya hal-hal yang berhubungan dengan perjanjian konsesi jasa. Pengungkapan pertama yaitu deskripsi perjanjian yang timbul antara pemberi konsesi dengan operator. Pengungkapan kedua yaitu kriteria dan persyaratan yang bersifat signifikan, dimana persyaratan tersebut dapat mempengaruhi waktu, jumlah, dan kepastian arus kas masa depan yang akan diterima oleh entitas. Pengungkapan ketiga yaitu sifat dan tingkatan yang ada berupa jumlah, waktu, nilai dari hak untuk menggunakan aset, kewajiban operator untuk menyediakan atau hak yang diperkirakan muncul dalam kegiatan penyediaan jasa, kewajiban untuk mengusahakan aset tetap, kewajiban untuk menyerahkan atau hak untuk memperoleh aset tertentu di akhir perjanjian konsesi, opsi pembaruan dan penghentian kontrak, serta hak dan kewajiban lain yang akan timbul di kemudian hari. Pengungkapan keempat yaitu kemungkinan adanya perubahan yang terjadi dalam perjanjian konsesi jasa selama periode berjalan. Pengungkapan kelima yaitu berkaitan dengan pengklasifikasian perjanjian konsesi jasa dalam laporan keuangan perusahaan.

Selanjutnya pada paragraf 06A disebutkan bahwa pendapatan yang diterima dari kegiatan penyediaan layanan jasa publik termasuk pendapatan dan beban yang timbul dari pemberian jasa konstruksi harus diungkapkan setiap tahunnya dalam laporan keuangan perusahaan. Pendapatan yang 


\section{saki}

Studi Akuntansi \& Keuangan Indonesia

dimaksud dapat berupa aset keuangan maupun aset tak berwujud yang diperoleh perusahaan sebagai imbalan atas pemberian jasa tersebut. Lebih lanjut pada paragraf 07 disebutkan bahwa pengungkapan yang disyaratkan pada paragraf 06 dapat ditampilkan secara terpisah untuk setiap perjanjian konsesi jasa, atau dikelompokkan berdasarkan jenis kelompok perjanjian yang memiliki sifat/karakteristik yang sama.

\section{Metode Penelitian}

Penelitian ini menggunakan metode kualitatif dengan teknik analisis isi dan wawancara narasumber. Menurut Roberts, (2015), analisis isi merupakan metode yang digunakan untuk menyimpulkan informasi yang terkandung dalam suatu suatu objek penelitian secara objektif, sistematis, dan dapat diaplikasikan secara umum. Peneliti akan ini melakukan analisis mengenai kesesuaian antara Standar Akuntansi Keuangan (SAK), pendapat narasumber, dan implementasi yang dijalankan oleh perusahaan berdasarkan keterangan yang disebutkan dalam Catatan Atas Laporan Keuangan (CaLK) perusahaan. Data yang digunakan dalam analisis ini adalah laporan keuangan PT Citra Marga Nusaphala Persada Tbk. dan PT Jasa Marga (Persero) Tbk. selaku perusahaan penyedia jasa jalan tol di Indonesia dari tahun 2014 sampai dengan tahun 2018 yang diperoleh dari laman perusahaan. Isi dari laporan keuangan tersebut akan dibandingkan dengan PSAK 19 (2015) tentang Aset Tak berwujud, ISAK 16 (2014) tentang Perjanjian Konsesi Jasa, dan ISAK 22 (2014) tentang Perjanjian Konsesi Jasa - Pengungkapan, termasuk PSAK lainnya yang relevan dan berlaku dengan analisis data sesuai dengan periode yang digunakan dalam penelitian ini. Selain itu, wawancara dengan narasumber yang relevan digunakan dalam penelitian ini untuk mengkonfirmasi data laporan keuangan dengan kondisi praktik di lapangan.

Wawancara merupakan sebuah proses yang dilakukan dalam rangka pengumpulan data dengan melakukan kegiatan tanya- jawab sepihak dengan langkah yang sistematis untuk memenuhi tujuan penelitian (Sugiyono, 2017). Dengan menggunakan metode ini, data yang diperoleh dari Catatan Atas Laporan Keuangan (CaLK) akan dibandingkan dengan keterangan dan pendapat dari informan sebagai narasumber penelitian. Informan pertama yaitu dosen akuntansi keuangan sekaligus pengurus Ikatan Akuntan Indonesia yang memberikan pendapat mengenai perjanjian konsesi jasa berdasarkan standar akuntansi keuangan. Informan kedua yaitu akuntan sekaligus praktisi yang memiliki pengalaman dalam bidang penyediaan jasa jalan tol dan memberikan informasi mengenai implementasi perjanjian konsesi jasa 


\section{saki}

Studi Akuntansi dan Keuangan Indonesia, Vol. 3, No. 2, 2020 | E-ISSN: 2654-6221

Studi Akuntansi \& Keuangan Indonesia

jalan tol di Indonesia. Adapun item wawancara meliputi aturan dan implementasi standar akuntansi keuangan yang sudah diatur berdasarkan standar akuntansi keuangan, praktik umum yang dilakukan, dan terkait dengan perusahaan penyedia jasa jalan tol di Indonesia. Hasil dari analisis data dan wawancara tersebut selanjutnya dijabarkan dan ditarik kesimpulan terkait dengan kesesuaian implementasi dan pengungkapannya.

\section{Hasil dan Diskusi}

Berdasarkan hasil wawancara yang sudah dilakukan kepada dua informan sebagai sumber data penelitian ini, diperoleh pengertian perjanjian konsesi jasa sebagai berikut:

Tabel 1 Pendapat Informan tentang Perjanjian Konsesi Jasa

\begin{tabular}{|c|c|}
\hline Sumber Informasi & Pengertian perjanjian konsesi jasa \\
\hline $\begin{array}{l}\text { Pernyataan dalam } \\
\text { ISAK } 16\end{array}$ & $\begin{array}{l}\text { Perjanjian jasa kontraktual yang dibuat pemerintah untuk menarik partisipasi swasta } \\
\text { dalam kegiatan pengembangan, pembiayaan, pengoperasian, dan penyelenggaraan } \\
\text { infrastruktur, baik yang sudah tersedia atau harus dibangun selama periode perjanjian } \\
\text { jasa. }\end{array}$ \\
\hline Pendapat Informan 1 & $\begin{array}{l}\text { Perjanjian konsesi jasa adalah perjanjian antara pemerintah dengan pihak ketiga, bisa } \\
\text { swasta maupun BUMN untuk menyediakan aset tertentu untuk dikelola dalam waktu } \\
\text { tertentu sesuai dengan perjanjian. Aset tersebut akan jadi milik pemerintah ketika } \\
\text { masa kontrak itu habis. }\end{array}$ \\
\hline Pendapat Informan 2 & $\begin{array}{l}\text { Perjanjian konsesi jasa ini merupakan kontrak untuk mengelola jalan tol dengan } \\
\text { tujuan untuk menutup seluruh biaya investasi yang dikeluarkan perusahaan untuk } \\
\text { mendapatkan aset tersebut, baik dengan membangun sendiri atau membeli hak itu } \\
\text { dari pihak lain. Pendapatan dari pengelolaan jalan tol selama kurun waktu tertentu, } \\
\text { biasanya } 25 \text {, 30, atau } 40 \text { tahun ini yang digunakan untuk menutup seluruh biaya } \\
\text { perolehan aset tersebut sesuai dengan kontrak yang sudah disepakati. Ketika waktu } \\
\text { mengelola habis maka aset tersebut akan dikembalikan kepada pemerintah. }\end{array}$ \\
\hline
\end{tabular}

Berdasarkan analisis yang dilakukan terhadap ISAK 16 (2014), laporan keuangan kedua perusahaan, dan wawancara dengan narasumber, perjanjian konsesi jasa jalan tol yang dilakukan oleh kedua perusahaan merupakan perjanjian kerja sama yang dilakukan dengan pemerintah untuk mengusahakan infrastruktur berupa jalan tol. Isi dalam perjanjian konsesi jasa ini mencakup seluruh aktivitas yang berkaitan dengan penyediaan jalan tol, mulai dari kegiatan pembangunan sampai aset siap digunakan. Selain itu, perusahaan juga berhak untuk mengoperasikan dan wajib untuk memelihara selama masa konsesi setelah jalan tol tersebut selesai dibangun. Ketika masa konsesi habis, perusahaan wajib untuk menyerahkan aset jalan tol yang sudah dibangun dan dioperasikan kepada pemerintah melalui Badan Pengatur Jalan Tol (BPJT). Perusahaan juga harus memperhatikan syarat dan kewajiban lain yang harus dipenuhi sebelum aset tersebut dikembalikan kepada pemerintah. 


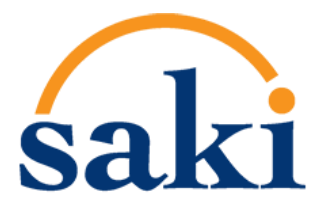

Studi Akuntansi dan Keuangan Indonesia, Vol. 3, No. 2, 2020 | E-ISSN: 2654-6221

Studi Akuntansi \& Keuangan Indonesia

Selanjutnya mengenai pengakuan atas hak konsesi tersebut, informan memaparkan mengenai

pengakuan yang dapat dilakukan oleh operator atas infrastruktur yang dikelolanya.

Tabel 2 Pendapat Informan tentang Pengakuan Operator atas Infrastruktur

\begin{tabular}{ll}
\hline \multicolumn{1}{c}{ Sumber Informasi } & \multicolumn{1}{c}{ Pengakuan perjanjian konsesi jasa } \\
\hline Pernyataan dalam & Perjanjian konsesi jasa oleh operator diakui sebagai aset tak berwujud oleh operator \\
ISAK 16 & karena operator tidak berhak untuk mengendalikan pemakaian infrastruktur konsesi. \\
& Perusahaan hanya memiliki akses untuk menyediakan jasa pelayanan kepada publik \\
& berdasarkan kepentingan pemberi konsesi sesuai kontrak antara pemberi konsesi \\
& dengan operator. \\
& Pengakuan perjanjian konsesi jasa tergantung bagaimana owner (pemerintah) \\
& mengembalikan biaya yang dikeluarkan operator dalam membangun aset tersebut. \\
& Suatu perjanjian lebih cocok diakui sebagai aset tak berwujud karena operator tidak \\
& mempunyai hak untuk memanfaatkan aset tak berwujud selama umur manfaat jalan \\
& melainkan selama masa kontrak atau kesepakatan antara pemerintah dengan operator. \\
& Apabila mengacu pada IAS sebagai acuan penyusunan PSAK dan ISAK, lebih cocok \\
& untuk diakui sebagai aset tak berwujud daripada aset tetap perusahaan. Perlakuannya \\
& lain lagi apabila disebutkan perusahaan akan menerima pembayaran berupa kas atau \\
& aset keuangan lainnya, maka perusahaan akan mengakui piutang dalam laporan \\
& keuangannya. \\
& Perusahaan bisa mengakui kontrak ini sebagai aset tak berwujud dalam laporan \\
& keuangannya.
\end{tabular}

Perusahaan dapat mengakui perjanjian konsesi jasa sebagai aset tak berwujud apabila dalam perjanjian konsesi jasa tersebut disebutkan bahwa operator mempunyai hak untuk mengoperasikan, mengelola, dan wajib untuk menyediakan jasa layanan jalan tol kepada publik selama masa konsesi. Untuk memastikan apakah kedua perusahaan penyedia jalan tol sudah mengakui perjanjian konsesi jasa dengan tepat atau belum, dilakukan analisis lanjutan beberapa poin pengujian yang disebutkan dalam ISAK 16 (2014).

PT Citra Marga Nusaphala Persada Tbk. dan PT Jasa Marga (Persero) Tbk., telah memenuhi enam ciri-ciri umum dan pengujian kerangka konseptual akuntansi yang disebutkan dalam paragraf 03 ISAK 16 (2014). Ciri umum pertama yaitu kedua perusahaan ini menyediakan pelayanan jasa jalan tol atas nama pemerintah, bukan atas nama operator sendiri dan tunduk pada regulasi pemerintah selaku pemberi konsesi. Ciri umum kedua yaitu pihak yang terlibat dalam perjanjian ini terdiri dari pemerintah yang diwakili oleh Badan Pengatur Jalan Tol (BPJT) selaku entitas publik yang memberikan hak konsesi dan kedua perusahaan yang bertindak sebagai operator selaku penerima hak konsesi dan penyedia jasa kepada masyarakat. Ciri umum ketiga yaitu perusahaan selaku operator yang bertindak sebagai penyedia jasa bertanggung jawab untuk mengelola infrastruktur berupa aset jalan tol dan memberdayakan potensi yang ada melalui penyediaan jasa dalam kegiatan operasionalnya. Ciri umum keempat yaitu kebijakan 


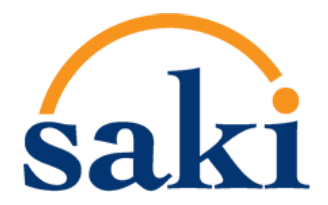

Studi Akuntansi dan Keuangan Indonesia, Vol. 3, No. 2, 2020 | E-ISSN: 2654-6221

Studi Akuntansi \& Keuangan Indonesia

penentuan tarif tol yang akan dibebankan kepada pengguna jasa mengacu pada peraturan yang dikeluarkan oleh pemerintah dan akan tarif tersebut akan dievaluasi setiap dua tahun sekali. Ciri umum yang kelima yaitu infrastruktur jalan tol akan diserahkan kepada Badan Pengatur Jalan Tol (BPJT) dengan memperhatikan syarat atau ketentuan yang sudah ditetapkan oleh pemerintah di akhir masa konsesi.

Selanjutnya dilakukan pengujian lanjutan mengenai kesesuaian antara kerangka akuntansi dengan praktik perjanjian konsesi jasa yang dilakukan kedua perusahaan tersebut. Hasil dari ketiga poin pengujian yang dilakukan menunjukkan bahwa perjanjian ini masuk dalam ruang lingkup yang dibahas dalam ISAK 16 (2014). Hasil pengujian pertama menunjukkan bahwa pemerintah menetapkan jenis jasa yang harus disediakan oleh kedua perusahaan berupa layanan jasa jalan tol kepada masyarakat sebagai konsumen. Tarif yang akan dibebankan kepada konsumen atas penggunaan jasa tiap ruas tol juga diatur dalam Keputusan Menteri PUPR dimana tarif tersebut akan dilakukan evaluasi secara berkala setiap dua tahun sekali dengan memperhatikan faktor ekonomi dan kesepakatan dengan operator selaku pengelola jalan tol. Pengujian kedua menunjukkan bahwa dalam Catatan atas Laporan Keuangan (CaLK) perusahaan terdapat klausul perjanjian yang menyebutkan infrastruktur berupa jalan tol akan diserahkan kepada pemerintah melalui Badan Pengatur Jalan Tol (BPJT) di akhir periode ketika masa konsesi sudah berakhir. Pengujian ketiga menunjukkan bahwa jalan tol yang sudah selesai dibangun melalui anak perusahaan atau diperoleh melalui kontrak kerja sama pembangunan dengan entitas lain digunakan dalam kegiatan bisnis operasi penyediaan jasa jalan tol dalam rangka perjanjian konsesi jasa antara perusahaan dengan pemerintah dan tidak ditujukan untuk dijual. Fakta tersebut ditemukan di dalam Catatan atas Laporan Keuangan (CaLK) kedua perusahaan.

Berdasarkan pengujian akhir yang dilakukan memberikan hasil bahwa perusahaan selaku operator dalam kontrak perjanjian konsesi jasa ini tidak menerima kas atau aset keuangan sebagai imbalan dalam kegiatan penyediaan infrastruktur yang, melainkan mendapatkan hak berupa lisensi untuk membebankan biaya kepada konsumen atas penggunaan jasa jalan tol yang sudah dibangun selama periode waktu tertentu. Perusahaan selaku operator dalam perjanjian jasa tersebut sudah tepat mengakui perjanjian konsesi sesuai dengan paragraf 11 ISAK 16 (2014). Praktik yang dilakukan oleh kedua perusahaan dalam mengklasifikasikan hak konsesi atas jalan tol sebagai aset tak berwujud sudah sesuai dengan pendapat 


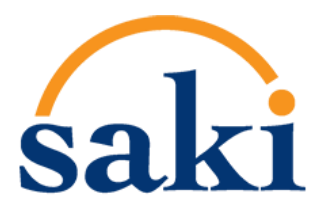

Studi Akuntansi dan Keuangan Indonesia, Vol. 3, No. 2, 2020 | E-ISSN: 2654-6221

Studi Akuntansi \& Keuangan Indonesia

kedua narasumber. Pengakuan sebagai aset tak berwujud dilakukan karena perusahaan hanya mengelola dan mengoperasikan aset jalan tol selama masa kontrak berlangsung. Apabila perusahaan memanfaatkan aset jalan tol selama umur manfaat, perusahaan baru dapat mengakui aset jalan tol sebagai aset tetap tetapi pengakuan tersebut tidak sesuai dengan apa yang disebutkan dalam ISAK 16 (2014).

Dalam laporan keuangan PT Citra Marga Nusaphala Persada Tbk. dan PT Jasa Marga (Persero) Tbk., tidak ditemukan adanya aset keuangan milik perusahaan yang timbul dari perjanjian konsesi jasa jalan tol dengan pemerintah. Aset keuangan yang dimiliki kedua perusahaan terdiri atas kas dan setara kas, investasi jangka pendek, piutang usaha, piutang pihak ketiga, berbagai macam aset lancar, dan aset keuangan yang siap untuk dijual seperti penyertaan modal saham kepada pihak lain yang dikelompokkan sebagai asat lancar. Dalam mengakui dan mengukur aset keuangan yang dimilikinya, kedua perusahaan mengacu pada PSAK 57 (2015): Provisi, Liabilitas Kontijensi, dan Aset Kontijensi. Untuk pengungkapannya, kedua perusahaan mengacu pada PSAK 60 (2016): Instrumen Keuangan: Pengungkapan.

Untuk aset tak berwujud yang dimiliki kedua perusahaan dalam kurun waktu 2014-2018 terdiri dari hak konsesi jalan tol yang timbul dari perjanjian konsesi jasa dan beberapa jenis aset tak berwujud lain yang dapat diidentifikasi dengan baik. Kriteria pertama yaitu hak konsesi jalan tol dapat dibedakan dengan aset tak berwujud lain. Apabila dilakukan pelepasan aset kepada entitas lain, perusahaan dapat menentukan pengurangan nilai hak konsesi tersebut pada tanggal penghentian pengakuannya. Kriteria kedua yang sudah dipenuhi yaitu aset konsesi yang dimiliki dua perusahaan berasal dari perjanjian pengusahaa jalan tol antara perusahaan dengan Badan Pengatur Jalan Tol (BPJT) selaku pemberi konsesi jasa dan memiliki lama masa kontrak konsesi jelas dan diungkapkan dalam CaLK perusahaan.

Tabel 3 Pendapat Informan mengenai Waktu Amortisasi Aset Tak Berwujud

\begin{tabular}{|c|c|}
\hline Sumber Informasi & Periode pengakuan amortisasi \\
\hline $\begin{array}{l}\text { Pernyataan dalam } \\
\text { PSAK } 19\end{array}$ & $\begin{array}{l}\text { Amortisasi dilakukan ketika aset sudah siap digunakan, sudah tersedia di tempat dan } \\
\text { siap untuk dioperasikan sesuai dengan tujuan penggunaan manajemen. Amortisasi } \\
\text { dihentikan ketika aset tersebut diklasifikasikan sebagai aset yang dimiliki untuk } \\
\text { dijual, dan aset tersebut berhenti digunakan. }\end{array}$ \\
\hline Pendapat & $\begin{array}{l}\text { Amortisasi dilakukan ketika aset yang dimiliki perusahaan sudah diresmikan dan siap } \\
\text { untuk digunakan. Untuk amortisasi ini bisa melihat pada PSAK 19: Aset Tak } \\
\text { berwujud. Amortisasi dihentikan ketika masa konsesi habis, diserahkan ke entitas } \\
\text { lain dengan dijual atau dikembalikan ke pemerintah. }\end{array}$ \\
\hline Pendapat & $\begin{array}{l}\text { Amortisasi dimulai ketika masa kontrak pengoperasian dimulai. Dalam konsesi } \\
\text { terdapat dua jenis kontrak, yaitu kontrak pembangunan dan kontrak pengoperasian. }\end{array}$ \\
\hline
\end{tabular}




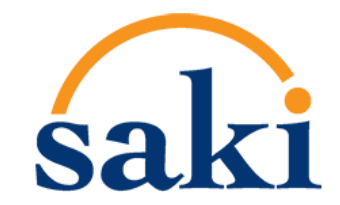

Studi Akuntansi \& Keuangan Indonesia

Ketika ada rentang waktu antara kontrak pembangunan dan kontrak pengoperasian tapi tidak signifikan (misal 1-2 bulan) biasanya tidak dilakukan amortisasi. Amortisasi dihentikan ketika masa kontrak pengoperasian habis dan dikembalikan ke pemerintah.

Amortisasi yang dilakukan menurut Catatan atas Laporan Keuangan (CaLK) perusahaan disebutkan bahwa perusahaan mulai melakukan amortisasi ketika aset konsesi siap digunakan selama masa pengoperasian atau setara dengan lama perjanjian konsesi setelah dikurangi dengan lama pembangunan aset jalan tol tersebut. Amortisasi oleh perusahaan diakhiri ketika masa konsesi berakhir dan seluruh hak amortisasi sudah diakui secara penuh oleh perusahaan. Praktik yang dilakukan oleh kedua perusahaan sudah tepat ketika aset sudah siap digunakan dapat dilakukan pembebanan. Dalam praktiknya apabila timbul jeda waktu seperti yang dipaparkan oleh narasumber kedua, jeda waktu tersebut masih menjadi tanggung jawab kontraktor dalam pengelolaannya. Oleh sebab itu perusahaan tidak perlu melakukan pembebanan amortisasi saat jalan tol tersebut sedang dalam masa penggratisan atau saat masa pengenalan kepada masyarakat. Di akhir periode pengoperasian saat dilakukan penyerahan konsesi kepada pemerintah, nilai konsesi yang dimiliki perusahaan diharapkan sudah habis tanpa ada sisa karena seluruh manfaat ekonomi yang akan diterima oleh perusahaan sudah diperoleh perusahaan sepenuhnya. Untuk melakukan amortisasi atas aset tersebut dapat dilakukan menggunakan metode yang sesuai dengan estimasi dan perkiraan manajemen berkaitan dengan perkiraan manfaat ekonomi yang diterima dari penggunaan aset tersebut.

Selanjutnya untuk metode amortisasi yang digunakan untuk mengamortisasi hak pengusahaan jalan tol, PT Jasa Marga (Persero) Tbk. menggunakan dua jenis metode dalam dua periode yang berbeda. Pada tahun 2014, perusahaan menggunakan metode amortisasi garis lurus untuk seluruh hak konsesi yang dimiliki. Mulai tahun 2015 sampai tahun 2018, perusahaan merubah metode amortisasi yang dimiliki menjadi dua metode. Perusahaan menggunakan metode unit pemakaian berdasarkan volume lalu lintas untuk aset konsesi berupa jalan dan jembatan, sedangkan untuk aset konsesi selain jalan dan jembatan menggunakan metode garis lurus. Untuk metode amortisasi yang dipakai oleh PT Citra Marga Nusaphala Persada Tbk. mulai dari tahun 2014 sampai 2018 tetap konsisten dengan menggunakan metode garis lurus untuk mengamortisasi hak konsesi yang dimiliki. 


\section{saki}

Studi Akuntansi \& Keuangan Indonesia

Tabel 4 Pendapat Informan mengenai Metode Amortisasi Hak Konsesi

\begin{tabular}{ll}
\hline \multicolumn{1}{c}{ Sumber Informasi } & \multicolumn{1}{c}{ Metode amortisasi } \\
\hline Pernyataan dalam & $\begin{array}{l}\text { Perusahaan dapat menggunakan metode yang sesuai dengan penggunaan aset dan } \\
\text { PSAK 19 }\end{array}$ \\
& $\begin{array}{l}\text { penerimaan manfaat ekonomi di masa depan. Apabila perusahaan tidak dapat } \\
\text { metode garis lurus atau metode lain yang diatur dalam SAK lain }\end{array}$ \\
Pendapat Informan 1 & Amortisasi pengusahaan jalan tol ini lebih cocok apabila menggunakan metode garis \\
& lurus karena waktu kontrak yang jelas kapan mulai dan berakhirnya. Perusahaan juga \\
& bisa memakai unit produksi dengan syarat penilaian dilakukan dengan tepat dan \\
& memiliki data yang sudah dianalisis dengan cermat. Untuk metode garis lurus lebih \\
& cocok untuk tipe lalu lintas dengan perubahan tidak signifikan. Untuk tol yang baru \\
& dibangun lebih cocok menggunakan volume produksi. \\
& Metode amortisasi yang dipakai tergantung dengan kebijakan manajemen dan jenis \\
& jalan tol yang dioperasikan. Untuk jenis jalan tol dengan lalu lintas tidak berkembang \\
& perusahaan seharusnya menggunakan garis lurus untuk mengamortisasi. Untuk jenis \\
& jalan tol yang masih sepi di awal, kemudian padat di belakang bisa menggunakan \\
& metode unit produksi. Tujuan dari manajemen menggunakan jenis amortisasi sendiri \\
& adalah menampilkan laporan keuangan yang bagus dan sesuai dengan standar \\
& akuntansi yang diperbolehkan tanpa mengaburkan informasi yang sebenarnya. \\
\hline
\end{tabular}

Kedua perbedaan penggunaan metode tersebut bisa terjadi karena jalan tol yang dioperasikan oleh PT Citra Marga Nusaphala Persada Tbk. memiliki volume pengguna yang stabil dan cenderung tidak mengalami perubahan yang signifikan setiap tahunnya. Disisi lain, sebagian aset jalan tol yang dioperasikan oleh PT Jasa Marga (Persero) Tbk. merupakan jalan tol yang baru selesai dibangun pada tahun 2017 dan 2018 karena pembangunan tol tersebut sempat terhenti. Pengguna jalan tol yang memanfaatkan jalan tersebut juga relatif masih berfluktuatif, belum stabil, dan diperkirakan akan dilalui banyak pengguna di masa yang akan datang. Oleh sebab itu, metode yang dipakai oleh perusahaan lebih cocok apabila menggunakan metode unit produksi. Kedua metode yang dipakai oleh kedua perusahaan sesuai dengan yang disebutkan dalam paragraf 97 PSAK 19 (2015) dengan pertimbangan bahwa manajemen dapat menggunakan metode amortisasi yang menunjukan pola pemanfaatan aset dan penerimaan manfaat ekonomi di masa depan serta sudah sesuai dengan pendapat yang disampaikan oleh kedua narasumber.

Tabel 5 Pendapat Informan mengenai Pengakuan Pendapatan Pengelolaan Jalan Tol

\begin{tabular}{cl}
\hline Sumber Informasi & \multicolumn{1}{c}{ Pengakuan Pendapatan dalam Perjanjian Konsesi Jasa } \\
\hline Pernyataan ISAK 16 & Seluruh pendapatan yang diperoleh dan beban yang timbul sehubungan dengan \\
& kegiatan penyediaan jasa konstruksi atau usaha peningkatan infrastruktur dapat \\
& dicatat dengan mengacu pada PSAK 34: Kontrak Konstruksi. Biaya pinjaman yang \\
& timbul dari kegiatan pembangunan dapat dikapitalisasikan ke aset yang dibangun \\
& selama pembangunan aset tersebut dilakukan sesuai dengan PSAK 26: Biaya \\
& Pinjaman. Operator berhak mengakui pendapatan atas jasa operasi yang diterima \\
& mengacu pada PSAK 23: Pendapatan. \\
Pendapat Informan 1 & Pendapatan yang timbul dari kegiatan membangun infrastruktur yang dilakukan \\
& sendiri oleh perusahaan diakui sebesar persentase penyelesaian pembangunan
\end{tabular}




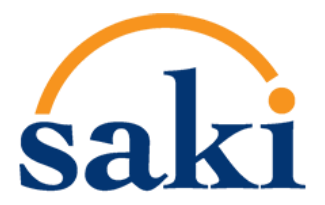

Studi Akuntansi \& Keuangan Indonesia

dikalikan dengan nilai kontrak, atau menggunakan metode zero profit dengan mengakui keuntungan pembangunan setelah infrastruktur selesai dibangun. Untuk beban diakui sebesar biaya yang sudah dikeluarkan untuk bahan baku langsung, akrual untuk gaji pegawai dan biaya lain termasuk bunga pinjaman apabila pembangunan dilakukan dengan utang. Selain itu juga bisa sebesar tagihan yang ditagih kontraktor.

Pendapat Informan 2 Pendapatan ada dua, pendapatan untuk membangun infrastruktur dan pendapatan penyediaan jasa jalan tol. Untuk membangun jalan tol bisa mengacu pada PSAK 34 tentang kontrak konstruksi. Secara garis besar untuk pendapatan membangun jalan tol diakui berdasarkan persentase penyelesaian dikalikan nominal kontrak atau seluruh biaya yang sudah dikeluarkan ditambah dengan biaya bunga dan margin keuntungan yang akan didapatkan oleh perusahaan. Untuk beban pembangunan jalan tol dihitung sebesar biaya yang sudah dikeluarkan ditambah dengan biaya bunga pinjaman di periode tersebut. Beban yang dikeluarkan diakui sesuai dengan prinsip akrual. Untuk pendapatan penyediaan jasa jalan tol, pendapatan diakui ketika pengguna melakukan tap kartu e-money dan gerbang pintu terbuka. Beban untuk penyediaan jasa jalan tol diakui secara periodik, ketika beban tersebut terjadi dan dicatat menurut prinsip akrual juga. Untuk beban perusahaan semuanya mengikuti aturan basis akrual

Selanjutnya, dalam CaLK perusahaan bahwa kedua perusahaan mengakui pendapatan dari pelaksanaan kegiatan konstruksi aset konsesi sehubungan dengan perjanjian konsesi jasa mengacu pada PSAK 34 (2014). Nilai pendapatan dari kegiatan tersebut oleh kedua perusahaan diukur menggunakan nilai wajar imbalan yang diterima atau akan diterima oleh perusahaan. PT Citra Marga Nusaphala Tbk. sepanjang tahun 2014 sampai 2018 mengakui pendapatan konstruksi berdasarkan metode persentase penyelesaian (percentage of completion method) untuk proyek yang dikerjakan dengan melihat kemajuan pembangunan sampai dengan tanggal pelaporan. Pendapatan yang diakui oleh beberapa anak perusahaan di bidang konstruksi yaitu PT Citra Waspphutowa, PT Citra Marga Lintas Jabar, dan PT Citra Karya Jabar Tol diakui sebesar kontrak pembangunan konstruksi tanpa menambahkan margin keuntungan tertentu karena perusahaan menunjuk BUMN Karya selaku pihak ketiga untuk melakukan pengerjaan konstruksi jalan tol yang dimilikinya.

Selain mengakui pendapatan dari kontrak pembangunan yang disepakati, perusahaan juga mengakui pendapatan lain seperti pendapatan yang timbul karena adanya perbedaan perintah yang dilakukan oleh klien dari kontrak yang sudah disepakati. Pendapatan tersebut berupa klaim atas pendapatan untuk mengganti beban yang timbul karena kesalahan klien dalam pelaksanaan kontrak, dan insentif karena perusahaan memberikan hasil yang sesuai atau melebihi harapan klien. Pendapatan tersebut dapat diakui selama dapat diukur dengan andal dan kemungkinan kemungkinan perusahaan mendapatkan pendapatan 


\section{saki}

Studi Akuntansi \& Keuangan Indonesia

cukup besar. Untuk biaya kontrak yang memiliki nilai lebih besar daripada tagihan yang dikirim dapat diakui sebagai piutang usaha, sedangkan uang muka dalam rangka proyek pembangunan yang nilainya lebih dari biaya pengeluaran kontrak aka diakui sebagai pendapatan diterima dimuka.

PT Jasa Marga (Persero) Tbk. mengakui pendapatan konstruksi dengan menggunakan metode costplus, yaitu mengakui seluruh biaya yang dapat dialokasikan secara langsung kepada jalan tol yang dibangun kemudian ditambah dengan margin yang ditetapkan. Manajemen menentukan margin dengan menggunakan perhitungan tertentu berdasarkan estimasi terbaik yang dimiliki oleh manajemen. Perusahaan mengakui metode pendapatan dengan metode cost-plus karena semua kegiatan konstruksi dilakukan dengan menunjuk perusahaan BUMN Karya selaku pihak ketiga untuk membangun seluruh jalan tol yang dioperasikannya. Penunjukan tersebut dilakukan karena perusahaan dapat lebih fokus pada bisnis utama pengelolaan jalan tol yang dioperasikannya. Informasi tersebut ditemukan saat dilakukan penelaahan Catatan atas Laporan Keuangan (CaLK) perusahaan dan analisis lanjutan pada pada bagian kewajiban kontraktor jangka pendek dan jangka panjang yang ada dalam laporan keuangan perusahaan. Kedua perusahaan tersebut dapat mengukur total pendapatannya secara andal dengan mengacu pada kontrak yang sudah disepakati. Selain itu, manfaat ekonomi berupa hak pengoperasian jalan tol juga dapat diperoleh secara pasti oleh perusahaan dan seluruh biaya yang dikeluarkan dapat diukur dengan andal serta realisasinya dapat dibandingkan dengan kontrak yang sudah ditentukan.

Jasa operasi yang disediakan oleh perusahaan dalam perjanjian konsesi ini berupa penyediaan jasa jalan tol dan jasa pendukung lain dalam rangka pemanfaatan jalan tol kepada masyarakat. Dalam memberikan jasa tersebut, perusahaan memiliki hak untuk membebankan biaya kepada pengguna atas penggunaan jasa yang diberikan dalam menggunakan jalan tol tersebut atau jasa lain yang sudah dilakukan oleh perusahaan kepada konsumen pengguna jasa. Perusahaan sudah memenuhi empat kriteria yang disebutkan dalam sebagai acuan untuk menentukan pengakuan pendapatan atas pemberian jasa secara andal yang disyaratkan pada paragraf 20 PSAK 23 (2014). Menurut Catatan atas Laporan Keuangan (CaLK) PT Citra Marga Nusaphala Persada Tbk., pendapatan jasa usaha jalan tol diakui oleh entitas pada saat dilakukan penjualan karcis tol kepada pengguna. Pendapatan dari aset konsesi yang dikelola secara penuh oleh perusahaan diakui sebesar pendapatan yang diterima dari penjualan karcis. Untuk pendapatan 


\section{saki}

Studi Akuntansi \& Keuangan Indonesia

dalam rangka perjanjian operasi dengan pihak lain, nilai pendapatan diakui sebesar nilai bersih, yaitu nilai pendapatan dari penjualan karcis setelah dikurangi dengan bagian pihak lain yang terlibat dalam perjanjian pengoperasian bersama aset jalan tol. Untuk pendapatan jasa sewa, perusahaan mengakui pendapatan selama masa sewa tersebut diberikan kepada pelanggan. Uang pembayaran yang diberikan pelanggan kepada perusahaan disajikan dalam akun pendapatan diterima dimuka.

Selanjutnya menurut Catatan atas Laporan Keuangan (CaLK) PT Jasa Marga (Persero) Tbk., perusahaan mengakui pendapatan usaha dari kegiatan pengoperasian jalan tol saat karcis dijual kepada konsumen penggunaan jalan. Untuk pendapatan tol dari kegiatan kerja sama pengoperasian jalan tol dengan investor, apabila entitas memiliki kuasa untuk mengoperasikan jalan tol tersebut maka pendapatan diakui pada saat dilakukan penjualan penjualan karcis kepada konsumen setelah dikurangi nilai pendapatan yang menjadi hak investor. Pendapatan berupa hak investor yang tidak memiliki kuasa penyelenggaraan pengelolaan jalan tol dicatat dalam akun angsuran liabilitas kerja sama operasi. Ketika terdapat selisih yang timbul antara jumlah yang dibayarkan dengan angsuran liabilitas kerja saman operasi, selisih tersebut dicatat sebagai pendapatan atau beban kerja sama operasi. Selanjutnya pendapatan berupa kas yang diterima oleh perusahaan yang berhubungan dengan pengalihan hak atas pendapatan tol di masa yang akan datang diakui sebagai pendapatan tangguhan dan diakui sebagai pendapatan selama jangka waktu pengalihan hak atas pendapatan tol tersebut. Untuk pendapatan dari kegiatan penyediaan jasa sewa iklan, lahan, rest area, dan jasa pengoperasian lainnya diakui selama masa sewa berlangsung. Jumlah yang belum direalisasikan dari jasa sewa tersebut dicatat pada akun pendapatan diterima dimuka. Untuk kegiatan sewa ruko, pendapatan tersebut akan ditangguhkan sampai dengan jangka tertentu sebagai pendapatan sewa diterima dimuka. Untuk pendapatan yang diperoleh berupa uang jaminan dari pelanggan, pendapatan tersebut akan diakui sebagai uang jaminan penyewa dalam laporan keuangan.

Selanjutnya PT Citra Marga Nusaphala Tbk. dan PT Jasa Marga (Persero) Tbk. dalam laporan keuangannya mengungkapkan bahwa beban yang ditanggung oleh perusahaan diakui ketika perusahaan menerima manfaat dari timbulnya beban tersebut atau timbul berdasarkan masa manfaat yang diperoleh oleh perusahaan dalam menjalankan operasi bisnisnya. Selain itu, perusahaan mengakui beban tersebut menggunakan basis penilaian secara akrual. Beban yang diakui oleh PT Citra Marga Nusaphala Tbk. terdiri 


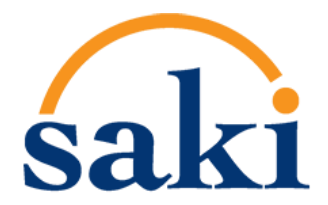

Studi Akuntansi dan Keuangan Indonesia, Vol. 3, No. 2, 2020 | E-ISSN: 2654-6221

Studi Akuntansi \& Keuangan Indonesia

dari beban pelayanan dan pemeliharaan, beban pendapatan dan pengumpulan tol, dan beban penyusutan properti investasi.

Pada Catatan atas Laporan Keuangan (CaLK) milik kedua perusahaan menyebutkan bahwa imbalan yang diperoleh perusahaan sehubungan dengan pelaksanaan kegiatan konstruksi tersebut diakui sebagai aset tak berwujud. Pengakuan tersebut dilakukan karena perusahaan mendapatkan hak berupa lisensi untuk mengoperasikan jalan tol yang sudah selesai dibangun. Dalam hak tersebut perusahaan juga dapat melakukan pembebanan biaya atas penggunaan aset jalan tol dalam rangka penyediaan jasa jalan tol kepada pengguna yang menyebabkan jumlah kas yang diperoleh perusahaan bergantung pada pemakaian jasa tersebut oleh masyarakat. Dalam implementasi oleh kedua perusahaan yang dijelaskan dalam laporan keuangan sudah benar dilakukan dan sesuai dengan ISAK 16 (2014) dan penuturan kedua narasumber.

Berdasarkan analisis yang dilakukan terhadap laporan keuangan perusahaan, kedua perusahaan sudah memenuhi tiga kriteria pengakuan provisi pelapisan jalan tol yang disebutkan paragraf 14 PSAK 57 (2015). Kriteria pertama yaitu perusahaan wajib melakukan pelapisan sesuai dengan kontrak perjanjian konsesi yang sudah ditandatangani dengan pemerintah, dan kewajiban tersebut muncul karena adanya peristiwa lalu berupa penggunaan aset jalan tol dalam rangka penyediaan jasa kepada masyarakat. Kriteria kedua yaitu kewajiban pelapisan jalan tol memiliki probabilitas penyelesaian cukup besar termasuk keluarnya arus kas perusahaan untuk melakukan penyelesaian kewajiban tersebut di masa yang akan datang berupa kegiatan pelapisan yang dilakukan oleh entitas. Kriteria ketiga yaitu perusahaan dapat menentukan estimasi provisi secara andal berdasarkan pertimbangan dan penilaian terbaik yang dilakukan oleh manajemen. Beban yang timbul untuk mengakui kewajiban pelapisan jalan tol diakui setiap tahun dan dilakukan kegiatan pencadangan secara berkala dengan mengacu pada intensitas penggunaan jalan. Nilai tercatat atas kewajiban pelapisan jalan tol tersebut merupakan nilai sekarang dari biaya untuk menyelesaikan kewajiban melapisi jalan tol di masa yang akan datang.

Pada praktiknya, ditemukan perbedaan implementasi dan pengungkapkan di kedua perusahaan. PT Citra Marga Nusaphala Persada Tbk. dalam laporan keuangannya hanya mengakui kewajiban pelapisan jalan tol dalam liabilitas jangka pendek saja. Dalam laporan keuangan PT Jasa Marga (Persero) Tbk. 


\section{saki}

Studi Akuntansi \& Keuangan Indonesia

ditemukan fakta bahwa perusahaan sudah mengakui kewajiban pelapisan jalan tol dengan menggunakan estimasi dan perkiraan terbaik manajemen. Selain itu, perusahaan juga sudah melakukan pengungkapan provisi pelapisan jalan tol baik sebagai liabilitas jangka pendek dan maupun sebagai liabilitas jangka panjang pada tahun 2014-2018.

Selanjutnya analisis yang dilakukan untuk mencari aktivitas pemenuhan kewajiban untuk memulihkan aset pada kondisi tertentu ketika akan dikembalikan kepada pemerintah tidak ditemukan karena masa konsesi yang dimiliki oleh kedua perusahaan tidak ada yang berakhir dalam kurun waktu tahun 2014 sampai tahun 2018. Meskipun tidak menemui, tetapi didapatkan persyaratan dalam Catatan atas Laporan Keuangan (CaLK) PT Jasa Marga (Persero) Tbk. yang menyebutkan pada akhir periode konsesi perusahaan harus melakukan pencadangan dana minimal $10 \%$ dari pendapatan tahun berakhirnya konsesi atau satu tahun sebelum berakhirnya konsesi dan jaminan pemeliharaan ini akan diberikan kepada Badan Pengatur Jalan Tol (BPJT). Pendapatan tersebut diberikan sebagai jaminan pemeliharaan aset selama 12 bulan setelah aset konsesi jalan tol dikembalikan kepada pemerintah.

Menurut CaLK kedua perusahaan, nilai kapitalisasi dari beban bunga yang diakui dihitung secara neto, yaitu beban bunga yang timbul setelah dikurangi pendapatan bunga yang diberikan oleh bank tersebut. Praktik tersebut sesuai dengan paragraf 12 PSAK 26 (2018) yaitu perusahaan mengkapitalisasi dengan mengurangi biaya pinjaman aktual setelah dikurangi pendapatan investasi sementara untuk jenis pinjaman yang memang ditujukan untuk memperoleh aset konsesi tersebut. Penentuan bunga yang dapat dikapitalisasi ke dalam aset konsesi jalan tol dapat dilakukan dalam mudah karena disebutkan siapa yang menjadi kreditur, nominal pinjaman, suku bunga, dan jatuh tempo pembayaran pinjaman tersebut di akhir periode. Hal itu juga sudah sesuai dengan paragraf 26 PSAK 26 (2018) yang menyebutkan kriteria pengungkapan kapitalisasi bunga dalam kegiatan perolehan aset konstruksi.

Perjanjian konsesi jasa jalan tol yang dilakukan dengan pemerintah sudah jelas disebutkan dan diatur bahwa perusahaan tidak boleh mengakui perjanjian ini sebagai aset tetap sesuai dengan praktik kedua perusahaan yang sudah dibahas pada poin sebelumnya. Isi dari perjanjian itu bisa saja dari sisi pemerintah memberikan kepada operator berupa aset konsesi atau item lainnya yang dapat digunakan dalam kegiatan operasional bisnisnya. 


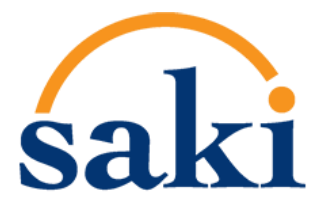

Studi Akuntansi dan Keuangan Indonesia, Vol. 3, No. 2, 2020 | E-ISSN: 2654-6221

Studi Akuntansi \& Keuangan Indonesia

Berdasarkan analisis yang dilakukan terhadap laporan keuangan kedua perusahaan tersebut ditemukan adanya aset pemberian pemerintah selaku pemberi konsesi yang diberikan kepada PT Jasa Marga (Persero) Tbk. berupa 13 ruas jalan tol untuk dioperasikan dalam kegiatan bisnisnya. Pemberian aset konsesi tersebut mengacu pada Keputusan Menteri Pekerjaan Umum No.242/KPTS/M/2006. Praktik yang dilakukan oleh PT Jasa Marga (Persero) Tbk. dalam menerima aset tersebut sudah tepat dengan mengakuinya sebagai aset tak berwujud dalam laporan keuangannya sesuai dengan paragraf 11 ISAK 16(2015). Perusahaan mengoperasikan aset tersebut selama 40 tahun mulai dari tahun 2015 sampai tahun 2045. Tidak terdapat pemberian lain dari pemerintah kepada kedua perusahaan berkaitan dengan perjanjian jasa yang dijalani antara perusahaan dengan pemerintah.

Tabel 6 Pendapat Mengenai Pengungkapan Perjanjian Konsesi Jasa

\begin{tabular}{ll}
\hline \multicolumn{1}{c}{ Sumber Informasi } & \multicolumn{1}{c}{ Pernyataan } \\
\hline Pernyataan dalam ISAK 22 tentang pengungkapan & Pengungkapan yang berhubungan dengan konsesi jasa \\
perjanjian konsesi jasa & sudah dijelaskan dalam SAK yang sudah ada seperti \\
& PSAK 19: Aset tak berwujud, PSAK 16: Aset Tetap. \\
& Beberapa kontrak eksekutori yang tidak dibahas dalam \\
& SAK yang sudah ada dapat memakai PSAK 57: \\
& Provisi, Liabilitas, Kontijensi, dan Aset Kontijensi. \\
& Untuk bagian interpretasi ini hanya memberikan \\
& pengungkapan tambahan dalam perjanjian konsesi \\
& jasa. \\
Pendapat Informan 1 & Pengungkapan seputar konsesi yang mengacu pada \\
& ISAK 16 dapat dilihat pada ISAK 22. Di ISAK 22 \\
& sudah dijelaskan secara detail dan rinci apa saja yang \\
& harus ditampilkan termasuk kesepakatan yang \\
& menentukan pengklasifikasian di laporan keuangan \\
& nanti apakah sebagai intangible asset maupun \\
& financial asset. \\
& Pengungkapan seputar konsesi jasa mengacu pada \\
& aturan yang berlaku. Perjanjian konsesi jalan tol ini \\
diakui sebagai aset tak berwujud, maka kita harus & mengacu pada SAK tentang aset tak berwujud itu dan \\
& SAK lain yang disebutkan pada ISAK 16.
\end{tabular}

Berdasarkan analisis yang dilakukan terhadap ISAK 22 (2014), penuturan narasumber, dan analisis terhadap laporan keuangan kedua perusahaan, dapat ditarik kesimpulan bahwa perusahaan sudah melakukan pengungkapan sesuai dengan ISAK 22 (2014): Perjanjian Konsesi Jasa - Pengungkapan dan PSAK 19 (2015): Aset Tak Berwujud. Pada bagian ini, akan dipaparkan hasil dua analisis pengungkapan hak operator dalam perjanjian konsesi jasa yang mengacu pada ISAK 22 (2014) dan pengakuan sebagai 


\section{saki}

Studi Akuntansi dan Keuangan Indonesia, Vol. 3, No. 2, 2020 | E-ISSN: 2654-6221

Studi Akuntansi \& Keuangan Indonesia

aset tak berwujud yang mengacu pada PSAK 19 (2015). Pengujian pengungkapan pertama dengan mengacu pada ISAK 22 (2014) tentang perjanjian konsesi jasa.

Tabel 7 Perbandingan Pengungkapan Perjanjian Konsesi Jasa Dua Perusahaan

\begin{tabular}{lcc}
\multicolumn{1}{c}{ Jenis Pengungkapan } & $\begin{array}{c}\text { PT Citra Marga } \\
\text { Nusaphala Persada } \\
\text { Tbk. }\end{array}$ & $\begin{array}{c}\text { PT Jasa Marga } \\
\text { (Persero ) Tbk. }\end{array}$ \\
\hline $\begin{array}{l}\text { Deskripsi perjanjian } \\
\text { Persyaratan signifikan yang dapat mempengaruhi jumlah, waktu, } \\
\text { dan kepastian arus kas masa depan }\end{array}$ & Ada & Ada \\
Hak penggunaan aset & Ada & Ada \\
Kewajiban untuk menyediakan jasa & Ada & Ada \\
Kewajiban untuk membangun aset tetap & Ada & Ada \\
Kewajiban untuk memberikan atau hak untuk menerima aset & Ada & Ada \\
tertentu pada akhir masa konsesi & Ada & Ada \\
Opsi pembaruan dan penghentian & & Ada \\
Perubahan dalam perjanjian yang terjadi selama periode berjalan & Ada & Ada \\
Pengklasifikasian perjanjian konsesi jasa & Ada & Ada \\
Jumlah pendapatan dan laba-rugi atas pertukaran jasa konstruksi & Ada & Ada \\
dengan aset keuangan atau aset tak berwujud & Ada & \\
\hline
\end{tabular}

Pengungkapan pertama yaitu kedua perusahaan telah mendeskripsikan secara jelas jenis perjanjian konsesi jasa yang dilakukan dengan pemerintah. Perjanjian konsesi jasa yang dimaksud termasuk kewajiban untuk membangunan dan meningkatan kapasitas infrastruktur tol yang dimiliki serta menyediakan jasa jalan tol kepada masyarakat dalam kurun waktu tertentu. Pengungkapan kedua yaitu kedua perusahaan telah mengungkapkan persyaratan signifikan yang dapat mempengaruhi penerimaan arus kas masa depan oleh entitas. Persyaratan tersebut seperti lama waktu konsesi, tanggal penetapan tarif tol untuk ruas tertentu, dan negosiasi perpanjangan konsesi jalan yang dilakukan oleh entitas dengan pemerintah yang dijelaskan dalam laporan keuangan perusahaan. Pengungkapan ketiga yaitu mengenai penggunaan aset jalan tol termasuk ruang yang ada untuk dimanfaatkan dalam kegiatan operasi bisnis, kewajiban untuk menyediakan sarana pendukung dan keamanan pengguna jalan tol, kewajiban untuk melakukan pelapisan jalan tol setiap periode. Selain itu perusahaan selaku operator diwajibkan untuk mengembalikan aset konsesi kepada pemerintah juga diungkapkan dalam Catatan atas Laporan Keuangan (CaLK) perusahaan. Dalam laporan keuangan PT Jasa Marga (Persero) Tbk. juga ditemukan kewajiban untuk menyediakan uang jaminan pemeliharaan sebesar 10\% kepada Badan Pengatur Jalan Tol (BPJT) waktu 6 bulan sebelum kontrak berakhir dan menjamin kualitas selama 12 bulan setelah masa konsesi. 


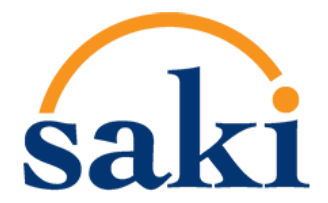

Studi Akuntansi dan Keuangan Indonesia, Vol. 3, No. 2, 2020 | E-ISSN: 2654-6221

Studi Akuntansi \& Keuangan Indonesia

Pengungkapan keempat yaitu pengungkapan yang dilakukan oleh perusahaan berupa opsi pembaruan Perjanjian Pengusahaan Jalan Tol (PPJT) yang beberapa kali diperbarui dengan masa waktu tertentu. Selain itu terdapat pengungkapan berupa adanya ancaman penghentian perjanjian konsesi ketika kedua perusahaan tersebut tidak mematuhi dan tidak dapat memenuhi persyaratan yang disebutkan dalam kontrak perjanjian tersebut. Pengungkapan kelima yaitu mengenai pengklasifikasian perjanjian konsesi jasa sebagai aset tak berwujud dalam laporan keuangan juga sudah dijelaskan dalam Catatan atas Laporan Keuangan (CaLK) perusahaan. Untuk pengakuan imbalan yang diperoleh dari kegiatan jasa konstruksi berupa aset tak berwujud sudah diungkapkan dan setiap tahunnya sesuai yang disebutkan dalam paragraf 06A ISAK 22 (2014). Selain itu, pengungkapan perjanjian konsesi jasa kedua perusahaan hanya membahas perjanjian konsesi jalan tol dan tidak terdapat perjanjian konsesi jasa lain yang dijalankan oleh kedua perusahaan.

Tabel 8 Perbandingan Pengungkapan Perjanjian Konsesi Jasa Sebagai Aset Tak Berwujud

\begin{tabular}{|c|c|c|c|}
\hline No & Jenis Pengungkapan & $\begin{array}{c}\text { PT Citra Marga } \\
\text { Nusaphala } \\
\text { Persada Tbk. }\end{array}$ & $\begin{array}{l}\text { PT Jasa Marga } \\
\text { (Persero)Tbk. }\end{array}$ \\
\hline 1 & Umur manfaat. & Ada & Ada \\
\hline 2 & Metode amortisasi. & Ada & Ada \\
\hline 3 & $\begin{array}{l}\text { Jumlah tercatat bruto dan akumulasi amortisasi dan akumulasi } \\
\text { penurunan pada awal dan akhir periode. }\end{array}$ & Ada & Ada \\
\hline 4 & $\begin{array}{l}\text { Pos laba rugi dan penghasilan komprehensif yang terpengaruh } \\
\text { amortisasi. }\end{array}$ & Ada & Ada \\
\hline 5 & $\begin{array}{l}\text { Rekonsiliasi atas nilai tercatat di awal dan akhir } \\
\text { periode yang menunjukkan: }\end{array}$ & & \\
\hline 6. & Penambahan dan sumber penambahan aset tak berwujud. & Ada & Ada \\
\hline 7. & $\begin{array}{l}\text { Rugi penurunan nilai yang diakui dalam laba rugi periode } \\
\text { berjalan sesuai dengan PSAK } 48 \text {. }\end{array}$ & Ada & Tidak Ada \\
\hline 8. & Jumlah amortisasi setiap periode. & Ya & $\mathrm{Ya}$ \\
\hline 9. & $\begin{array}{l}\text { Perubahan yang terjadi terhadap nilai tercatat aset dalam satu } \\
\text { periode. }\end{array}$ & Ada & Ada \\
\hline
\end{tabular}

Pembahasan selanjutnya terkait dengan perjanjian konsesi jasa sebagai aset tak berwujud. Pengungkapan pertama yaitu kedua perusahaan sudah mengungkapkan masa kontrak konsesi jasa yang dimiliki, mulai dari tanggal dimulainya kontrak sampai berakhirnya perjanjian konsesi, termasuk tarif amortisasi yang dibebankan setiap tahunnya dalam laporan keuangan perusahaan. Pengungkapan kedua yaitu kedua perusahaan sudah mengungkapkan metode amortisasi yang dipakai untuk mengamortisasi aset konsesi yang dimiliki, termasuk perubahan metode amortisasi yang digunakan oleh PT Jasa Marga (Persero) Tbk. mulai tahun 2015. Pengungkapan ketiga yaitu kedua perusahaan sudah mengungkapkan 


\section{saki}

Studi Akuntansi \& Keuangan Indonesia

perubahan nilai aset konsesi yang terdiri dari nilai awal, akumulasi amortisasi, akumulasi kerugian penurunan nilai di awal dan akhir periode pelaporan, termasuk kerugian penurunan nilai di tahun 2014 yang diakui oleh PT Citra Marga Nusaphala Persada Tbk. Pengungkapan keempat yaitu kedua perusahaan sudah mengungkapkan akun laba rugi dan penghasilan komprehensif yang terpengaruh dari adanya perhitungan beban amortisasi tahun berjalan. Pengungkapan kelima yaitu kedua perusahhaan sudah mengungkapkan rekonsiliasi nilai tercatat dari semua aset tak berwujud yang dimiliki selama tahun tahun 2014-2018 dalam laporan keuangannya.

\section{Kesimpulan, Implikasi, dan Keterbatasan}

Implementasi akuntansi atas hak konsesi jalan tol pada perusahaan yang digunakan dalam penelitian ini sudah sesuai dengan standar akuntansi keuangan yang berlaku. Perjanjian konsesi jasa jalan tol yang dilaksanakan oleh PT Citra Marga Nusaphala Persada Tbk. dan PT Jasa Marga (Persero) Tbk. merupakan implementasi dari program Kerjasama Pemerintah dengan Badan Usaha (KPBU) dalam rangka penyediaan infrastruktur dan pelayanan umum kepada masyarakat. Pada perjanjian konsesi jasa ini terdapat dua pihak yang terlibat. Pihak pertama yaitu perusahaan yang berkedudukan sebagai operator yang mempunyai kewajiban untuk mengusahakan keberadaan infrastruktur berupa jalan tol. Operator juga berhak untuk mengoperasikan aset jalan tol yang sudah selesai dibangun selama masa kontrak konsesi yang sudah diberikan oleh pemerintah kepada perusahaan. Pihak kedua yaitu Badan Pengatur Jalan Tol (BPJT) yang berkedudukan sebagai regulator bertugas untuk menetapkan regulasi yang harus dipatuhi dan dijalankan oleh operator dalam melaksanakan perjanjian konsesi jasa ini. BPJT juga berkewajiban untuk menjamin kelancaran pelaksanaan pembangunan aset jalan tol pada masa perjanjian. Kedudukan operator dan pemerintah sesuai dengan ruang lingkup yang disyaratkan dalam ISAK 16 (2014).

Selanjutnya, pengungkapan akuntansi atas hak konsesi sudah sesuai dengan standar akuntansi keuangan yang berlaku. Kedua perusahaan sudah melakukan pengungkapan hak operator dalam perjanjian konsesi jasa yang terdiri dari lima poin pengungkapan. Pengungkapan ini sudah sesuai dengan ISAK 22 (2014): Perjanjian Konsesi Jasa - Pengungkapan. Kedua perusahaan sudah melakukan pengungkapan perjanjian konsesi jasa sebagai aset tak berwujud yang terdiri dari lima poin pengungkapan umum untuk 


\section{saki}

Studi Akuntansi \& Keuangan Indonesia

jenis aset tak berwujud dengan masa manfaat yang terbatas. Pengungkapan ini sudah sesuai dengan pengungkapan yang disebutkan pada PSAK 19 (2015): Aset Tak Berwujud.

Terdapat beberapa keterbatasan yang dihadapi dalam mengulas implementasi perjanjian konsesi jasa jalan tol di Indonesia. Pertama, penelitian ini hanya meninjau implementasi perjanjian konsesi yang dilakukan dua perusahaan penyediaan jasa jalan tol di Indonesia, yaitu PT Jasa Marga (Persero) Tbk. dan PT Citra Marga Nusaphala Persada Tbk. Pemilihan objek penelitian ini didasarkan pada jenis kegiatan bisnis utama perusahaan, yaitu perusahaan yang bergerak di bidang penyediaan jasa jalan tol. Selain itu, kecukupan pengungkapan informasi di dalam laporan keuangan juga dijadikan pertimbangan lanjutan karena informasi tersebut digunakan sebagai sumber literatur untuk melakukan analisis dalam penelitian ini. Kedua, penelitian ini tidak dapat melakukan verifikasi dan konfirmasi secara langsung kepada manajemen mengenai pertimbangan penggunaan kebijakan dan asumsi yang dipakai dalam melakukan penyusunan laporan keuangan.

Berdasarkan temuan dalam penelitian ini, perusahaan penyelenggara hak konsesi jalan tol perlu melakukan pengungkapkan lebih rinci terkait dengan adanya penurunan nilai aset konsesi, meninjau kembali metode yang digunakan dalam melakukan amortisasi atas nilai tercatat dari aset konsesi yang dimiliki. Selain itu, perusahaan perlu meninjau ulang pengakuan provisi pelapisan jalan tol dalam laporan keuangannya menampilkan rincian beban yang timbul dari kegiatan penyediaan jasa jalan tol dan kegiatan lain sesuai jenis kelompok pendapatannya. Selanjutnya, Otoritas Jasa Keuangan (OJK) sebaiknya dapat mengawasi lebih ketat atas implementasi Peraturan Standar Akuntansi Keuangan (PSAK) oleh perusahaan penyelenggara hak konsesi jalan tol yang listed di Bursa Efek Indonesia terkait dengan tingkat kepatuhan dan ketaatan perusahaan dalam menerapkan standar akuntansi yang sudah disyaratkan sebelumnya. Tindakan tersebut perlu dilakukan dengan tujuan untuk meminimalisir masalah yang timbul dan dapat merugikan investor maupun calon investor.

Untuk penelitian selanjutnya, hasil dari penelitian ini dapat dijadikan sebagai salah satu bahan literatur untuk melakukan analisis perbandingan implementasi perjanjian konsesi jalan tol yang dilakukan di negara lain. Contohnya kasus yang menarik untuk diulas dan dijadikan sebagai objek perbandingan adalah implementasi perjanjian konsesi jalan tol di Malaysia. Sistem di Negara Malaysia yang memberikan 


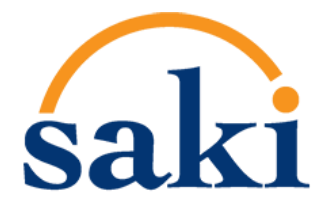

Studi Akuntansi dan Keuangan Indonesia, Vol. 3, No. 2, 2020 | E-ISSN: 2654-6221

Studi Akuntansi \& Keuangan Indonesia

jaminan hukum kepada operator untuk mempermudah perizinan pembangunan jalan tol membuat banyak pihak swasta yang ingin berinvestasi disana. Semakin cepat suatu jalan tol terbangun, hal itu akan membuat durasi pengoperasoan jalan tol menjadi lebih lama dan membuat keuntungan yang didapatkan meningkatkan. Perbedaan pola pengelolaan dan pengoperasian jalan tol antara Indonesia dengan Malaysia dan skema penentuan penentuan tarif jalan tol yang direview selama sembilan tahun sekali membuat penelitian selanjutnya bisa lebih menarik apabila dilakukan pembahasan dengan melakukan perbandingan implementasi perjanjian konsesi jasa yang dilakukan di negara selain Indonesia.

\section{DAFTAR PUSTAKA}

Abadiah, T. M., Hidayati, D. H. N., \& Mawardi, M. C. (2017). Analisis Pengaruh Aset Tidak Berwujud dan Kinerja Keuangan Terhadap Nilai Perusahaan. Jurnal Ilmiah Riset Akuntansi, 06 (04 Juni 2017), 53-67.

Badan Pengatur Jalan Tol. http://bpjt.pu.go.id/ (di akses 5 Mei 2020) .

Bappenas. (2019). Rancangan Teknokratik Rencana Pembangunan Jangka Menengah Nasional 2020 - 2024: Indonesia Berpenghasilan Menengah - Tinggi Yang Sejahtera, Adil, dan Berkesinambungan. $\quad$ Kementerian PPN/ 313. https://doi.org/10.1017/CBO9781107415324.004

Bel, G., \& Foote, J. (2012). Comparison of Recent Toll Road Concession Transactions in the United States and France. SSRN Electronic Journal, October 2007. https://doi.org/10.2139/ssrn.1847586

Bisnis.com. 2013. Beda Pengoperasian Jalan Tol di Malaysia dengan Indonesia. https://ekonomi.bisnis.com/read/20131029/45/183431/beda-pengoperasian-jalan-tol-dimalaysia-dengan-indonesia (di akses 16 Juni 2020).

Dwi Martani, et al. 2014. Akuntansi Keuangan Menengah Berbasis PSAK Buku 1 Edisi 2. Jakarta: Salemba Empat.

Firmansyah, A., Hertanto, K. M., \& Anastia, A. (2020a). Evaluasi pengungkapan aset tak berwujud pada perusahaan subsektor telekomunikasi di Indonesia. Bunga Rampai: Studi Kasus Akuntansi Keuangan, 149-178

Firmansyah, A., Sari, A. K., Maharani, Y. P. (2020b). Implementasi aset tak berwujud PT Telekomunikasi Indonesia (Persero) Tbk. Bisnis Net, 3(1), 52-61.

Hartanto, L., \& Firmansyah, A. (2019). Kapitalisasi aset tak berwujud yang dihasilkan secara internal oleh start up company. Info Artha, 3 (1), 29-41

Iek, M. (2013). Analisis Dampak Pembangunan Jalan Terhadap Pertumbuhan Usaha Ekonomi Rakyat di Pedalaman May Brat Provinsi Papua Barat (Studi Kasus di Distrik Ayamaru, Aitinyo, dan Aifat. Jurnal Ekonomi Kuantitatif Terapan, 06(1 Februari 2013), 30-40.

Ikatan Akuntan Indonesia. (2014). Interpretasi Standar Akuntansi Keuangan No. 16: Perjanjian Konsesi Jasa. Jakarta: Ikatan Akuntan Indonesia.

Ikatan Akuntan Indonesia. (2014). Interpretasi Standar Akuntansi Keuangan No. 22: Perjanjian Konsesi Jasa: Pengungkapan. Jakarta: Ikatan Akuntan Indonesia.

Ikatan Akuntan Indonesia. (2015). Pernyataan Standar Akuntansi Keuangan No. 19: Aset Tak Berwujud. Jakarta: Ikatan Akuntan Indonesia. 


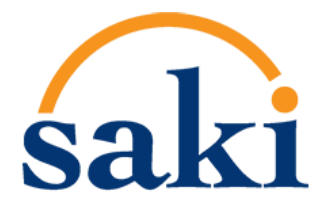

Studi Akuntansi dan Keuangan Indonesia, Vol. 3, No. 2, 2020 | E-ISSN: 2654-6221

Studi Akuntansi \& Keuangan Indonesia

Ikatan Akuntan Indonesia. (2014). Pernyataan Standar Akuntansi Keuangan No. 23: Pendapatan. Jakarta: Ikatan Akuntan Indonesia.

Ikatan Akuntan Indonesia. (2018). Pernyataan Standar Akuntansi Keuangan No. 26: Biaya Pinjaman. Jakarta: Ikatan Akuntan Indonesia.

Ikatan Akuntan Indonesia. (2014). Pernyataan Standar Akuntansi Keuangan No. 34: Kontrak Konstruksi. Jakarta: Ikatan Akuntan Indonesia.

Ikatan Akuntan Indonesia. (2014). Pernyataan Standar Akuntansi Keuangan No. 50: Instrumen Keuangan, Penyajian. Jakarta: Ikatan Akuntan Indonesia.

Ikatan Akuntan Indonesia. (2015). Pernyataan Standar Akuntansi Keuangan No. 55: Instrumen Keuangan, Pengakuan dan Pengukuran. Jakarta: Ikatan Akuntan Indonesia.

Ikatan Akuntan Indonesia. (2015). Pernyataan Standar Akuntansi Keuangan No. 57: Provisi, Liabilitas Kontinjensi, dan Aset Kontijensi. Jakarta: Ikatan Akuntan Indonesia.

Ikatan Akuntan Indonesia. (2016). Pernyataan Standar Akuntansi Keuangan No. 57: Instrumen Keuangan, Pengungkapan. Jakarta: Ikatan Akuntan Indonesia.

Kompas. (2019) Alasan Pemerintah Jokowi-JK Fokus Bangun Infrastruktur. https://money.kompas.com/read/2019/03/26/084500826/alasan-pemerintah-jokowi-jk-fokusbangun-infrastruktur?page=all (di akses 9 Juli 2020).

Isnaini, N. (2016). Pengaruh Intangible Asset Value, Struktur Kepemilikan, dan Kinerja Keuangan Terhadap Nilai Perusahaan. Skripsi. Fakultas Ekonomi. Universitas Muhammadiyah Surakarta : Surakarta

Kieso, D. E., Weygandt, J. J., \& Warfield, T. D. (2018). Intermediate Accounting: IFRS Edition, 3nd Edition. John Wiley \& https://books.google.co.id/books?id=_KOqBAAAQBAJ

Liputan6. (2018). Menteri PUPR_Konsesi Diperpanjang Jadi 50 Tahun, Tarif Tol Bisa Turun Rp 200 per Km. https://www.liputan6.com/bisnis/read/3399333/menteri-pupr-konsesi diperpanjang-jadi- 50 tahun-tarif-tol-bisa-turun-rp-200-per-km (di akses 12 Januari 2020).

Sekretariat Kabinet Republik Indonesia. (2017). Percepatan Infrastruktur dan Transformasi Ekonomi Indonesia. https://setkab.go.id/percepatan-infrastruktur-dan-transformasi-ekonomiindonesia/ (di akses 12 Juni 2020).

Muliaditia. (2014). Perhitungan Amortisasi Intangible Assets Atas Perjanjian Konsesi Jasa di PT Adhya Tirta Batam (ATB). Tugas Akhir. Program Studi Akuntansi. Politeknik Negeri Batam : Batam.

Murthashidiana, S., \& Pardede, R. P. (2015). The Analysis of the Implementation of PSAK 19 Rev. 2010: Intangible Assets to the Presentation and Disclosure of Financial Statements. ResearchGate, November 2015, 0-15.

Peraturan Menteri Pekerjaan Umum Republik Indonesia Nomor 16/PRT/M/2014/ tentang Standar Pelayanan Minimal Jalan Tol.

Peraturan Menteri Pekerjaan Umum Nomor: 295/Prt/M/2005 tentang Badan Pengatur Jalan Tol.

Peraturan Pemerintah Nomor 15 Tahun 2005 tentang Jalan Tol.

Peraturan Pemerintah Nomor 27 Tahun 2014 tentang Pengelolaan Barang Milik Negara/ Daerah.

Peraturan Presiden Republik Indonesia Nomor 38 Tahun 2015 tentang Kerjasama Pemerintah Dengan Badan Usaha Dalam Penyediaan Infrastruktur.

Prasetyo, B. B., \& Agustia, D. (2018). Analisis Dampak Rencana Penerapan Isak 16: Penyelenggaraan Prasarana Kereta Api Ringan/Light Rail Transit. Jurnal Akuntansi Universitas Jember. 66-82.

PT Citra Marga Nusaphala Persada Tbk. http://id.citramarga.com/ (di akses 2 Januari 2020).

PT Jasa Marga (Persero) Tbk. https://www.jasamarga.com/public/id/home.aspx (di akses pada 2 Januari 2020). 
Studi Akuntansi \& Keuangan Indonesia

Roberts, C. W. (2015). Content Analysis. International Encyclopedia of the Social \& Behavioral Sciences: Second Edition, 2008, 769-773. https: //doi.org/10.1016/B978-0-08-0970868.44010-9

Roberts, C. W. (2015). Content Analysis. International Encyclopedia of the Social \& Behavioral Sciences: Second Edition, 2008, 769-773. https://doi.org/10.1016/B978-0-08-0970868.44010-9

Rosdini, D. (2016). Relevansi Nilai Aset Tak Berwujud. Jurnal Akuntansi, 8(1), 65-85.

Sugiyono. (2017). Metode Penelitian Kuantitatif, Kualitatif, dan R\&D. Bandung : CV Alfabeta.

Suhandak, M. (2019). Pengaruh Pembangunan Infrastruktur Terhadap Pertumbuhan Ekonomi Dan Pemerataan Ekonomi Indonesia (Studi Pada Badan Pusat Statistik Tahun 2003-2017 ). Jurnal Administrasi Bisnis. Vol 70, No 1 (2019). 98-105.

Sumadiasa, I., Tisnawati, N., \& Wirathi, I. (2016). Analisis Pengaruh Pembangunan Infrastruktur Jalan, Listrik Dan Pma Terhadap Pertumbuhan Pdrb Provinsi Bali Tahun 1993-2014. EJurnal Ekonomi Pembangunan Universitas Udayana, 5(7), 925-947.

Todaro, M. P dan Smith, S. C . (2011), "Pembangunan Ekonomi", Edisi Sebelas. Jakarta, Erlangga.

Undang-Undang Republik Indonesia Nomor 38 Tahun 2004 tentang Jalan.

Undang-Undang Republik Indonesia Nomor 5 Tahun 1960 tentang Peraturan Dasar PokokPokok Agraria

Warren, C. S., Reeve, J. M., \& Duchac, J. E. (2018). Accounting (27 e). Cengage Learning. 